\title{
Luminescence properties of lanthanide complexes-based molecular alloys.
}

Roza Maouche $^{\mathrm{a}}$, Sabrina Belaid ${ }^{\mathrm{a} *}$, Belkacem Benmerad ${ }^{\mathrm{a}}$, Sofiane Bouacida ${ }^{\mathrm{b}, \mathrm{c}}$, Stéphane Freslon ${ }^{\mathrm{d}}$, Carole Daiguebonne ${ }^{\mathrm{d}}$, Yan Suffren ${ }^{\mathrm{d}}$, Guillaume Calvez ${ }^{\mathrm{d}}$, Kevin Bernot $^{\mathrm{d}}$, Claire Roiland ${ }^{\mathrm{d}}$, Laurent Le Pollès ${ }^{\mathrm{d}}$ and Olivier Guillou ${ }^{\mathrm{d}, *}$.

${ }^{a}$ Laboratoire de Physico-Chimie des Matériaux et Catalyse, Faculté des Sciences Exactes, Université de Bejaia, 06000 Bejaia, Algérie,

${ }^{\mathrm{b}}$ Département Sciences de la matière, Faculté des Sciences exactes et Sciences de la nature et de la vie, Université Larbi Ben M’hidi, Oum El Bouaghi, Algérie,

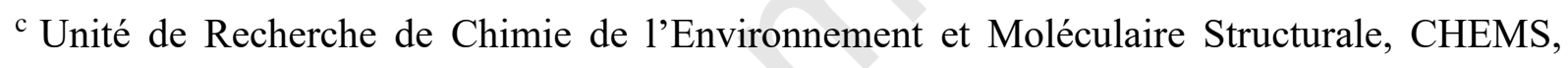
Université des frères Mentouri, Constantine 1, 25000, Algérie,

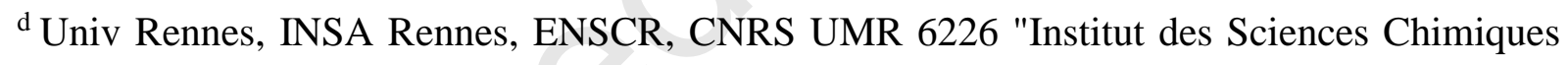
de Rennes", F-35000 Rennes, France.

* To whom correspondence should be addressed 


\section{ABSTRACT}

Six lanthanides complexes with chemical formula $\left[\mathrm{Ln}(\operatorname{phen})_{2}\left(\mathrm{NO}_{3}\right)_{3}\right](\mathrm{Ln}=\mathrm{Sm}(\mathbf{1})$, $\mathrm{Tb}(\mathbf{2}), \mathrm{Nd}(\mathbf{3}), \mathrm{Eu}(\mathbf{4}), \mathrm{Ho}(5)$ and Y (6), phen = 1,10-phenanthroline) were synthesized. 1 and 2 were obtained as single crystals by slow diffusion. Structural characterization was based on single crystal X-ray diffraction and IR and ${ }^{89}$ Y-NMR spectroscopies. NMR spectroscopic measurements were performed on $\left[\mathrm{Y}(\mathrm{phen})_{2}\left(\mathrm{NO}_{3}\right)_{3}\right](\mathbf{6})$ and $\left[\mathrm{Y}_{0.75} \mathrm{Lu}_{0.25}(\mathrm{phen})_{2}\left(\mathrm{NO}_{3}\right)_{3}\right](\mathbf{7})$. Compounds obtained as microcrystalline powders were characterized by powder X-ray diffraction. The complexes crystallize in the monoclinic system, space group $P 21 / n$. Each $\mathrm{Ln}(\mathrm{III})$ ion is surrounded by four $\mathrm{N}$ atoms from two bidentate phenanthroline ligands and six $\mathrm{O}$ atoms from three chelating nitrate groups. The phenanthroline ligand provides efficient sensitization of the complexes that exhibit sizeable luminescence under UV irradiation. Thermal properties have been studied. They confirm the absence of water molecules in the crystal structure. The complexes are thermally stable up to $290{ }^{\circ} \mathrm{C}$. Microcrystalline powders of hetero-lanthanide complexes, with global chemical formula $\left[\mathrm{Tb}_{1-x} \mathrm{Eu}_{x}(\mathrm{phen})_{2}\left(\mathrm{NO}_{3}\right)_{3}\right]$ (series 8) and $\left[\mathrm{Tb}_{1-x} \mathrm{Gd}_{x}(\text { phen })_{2}\left(\mathrm{NO}_{3}\right)_{3}\right]$ (series 9) were synthesized. Their photo-physical properties have been investigated. They demonstrate that luminescent molecular alloys can be obtained from lanthanides complexes and not only from hetero-nuclear coordination polymers as previously reported.

\section{KEYWORDS:}

Lanthanide Complexes, Phenanthroline, Crystal Structure, Luminescence, Thermal Stability. 


\section{INTRODUCTION}

Lanthanide coordination compounds attract a considerable attention due to their fascinating topologies, ${ }^{[1-2]}$ and their potentially applicable magnetic and optical properties. ${ }^{[3-}$ ${ }^{13]}$ All $\mathrm{Ln}^{3+}$ ions except $\mathrm{La}^{3+}$ and $\mathrm{Lu}^{3+}$ can generate luminescence from ultraviolet $\left(\mathrm{Gd}^{3+}\right)$ to visible $\left(\mathrm{Pr}^{3+}, \mathrm{Sm}^{3+}, \mathrm{Eu}^{3+}, \mathrm{Tb}^{3+}, \mathrm{Dy}^{3+}, \mathrm{Ho}^{3+}, \mathrm{Er}^{3+}, \mathrm{Tm}^{3+}\right)$ and near infrared $\left(\mathrm{Pr}^{3+}, \mathrm{Nd}^{3+}, \mathrm{Sm}^{3+}\right.$, $\left.\mathrm{Dy}^{3+}, \mathrm{Ho}^{3+}, \mathrm{Er}^{3+}, \mathrm{Tm}^{3+}, \mathrm{Yb}^{3+}\right) \cdot{ }^{[14]}$ Absorption coefficients of $\mathrm{Ln}^{3+}$ ions are weak because of the forbidden $\mathrm{f}-\mathrm{f}$ transitions that make direct excitation of the metal ion inefficient. In order to enhance emission efficiency, a $\pi$-conjugated organic aromatic ligand can be used that can participate to lanthanide ion excitation via the so called antenna-effect. ${ }^{[15]}$

It has been demonstrated that hetero-lanthanide-based coordination polymers can be considered as molecular alloys ${ }^{[16]}$ because of the chemical similarity of lanthanide ions. ${ }^{[17-19]}$ They are promising systems for technological applications such as thermometric probes, ${ }^{[20-21]}$ for instance. However they very often present limited quantum yields, in part because of the proximity of the lanthanide ions and of the presence of $\mathrm{C}-\mathrm{H}$ or $\mathrm{O}-\mathrm{H}$ vibrators in their first coordination sphere. Actually, it is difficult to find ligands that both prevent from solvent molecules coordination and allow for the formation of extended frameworks. Indeed, the ideal ligand should be bulky, at least bi-functional and should present an extended conjugated system that would allow efficient antenna effect. In this context, lanthanide complexes-based molecular alloys could constitute a promising alternative to coordination polymers because it makes possible the design of soluble lanthanide-based complexes. Additionally, carefully chosen ligands with bulky character can prevent from solvent molecules coordination via steric hindrance and can allow an enhancement of the luminescence of the targeted compound.

Aromatic N-donors ligands such as 1,10-phenanthroline (hereafter symbolized as phen) are known for being efficient sensitizers of lanthanides ions because they absorb and 
efficiently transfer energy to the $\mathrm{Ln}^{3+}$ excited states. ${ }^{[22]} \mathrm{A}$ number of $\left[\mathrm{Ln}(\mathrm{phen})_{2}\left(\mathrm{NO}_{3}\right)_{3}\right]$ complexes have been reported to date with $\mathrm{Ln}=\mathrm{Y},{ }^{[23]} \mathrm{La},{ }^{[24-25]} \mathrm{Ce},{ }^{[26]} \mathrm{Pr},{ }^{[27]} \mathrm{Nd},{ }^{[27]} \mathrm{Sm},{ }^{[27]}$ $\mathrm{Eu},{ }^{[27-32]} \mathrm{Gd},{ }^{[28]} \mathrm{Tb},{ }^{[30,33]} \mathrm{Dy},{ }^{[22,}{ }^{27,},{ }^{34]} \mathrm{Ho},{ }^{[35]} \mathrm{Er},{ }^{[36]} \mathrm{Yb},{ }^{[25,37]}$ and $\mathrm{Lu}^{[38]}$ but their luminescent properties have not been studied in details except for the dysprosium-based complex. ${ }^{[22]}$

Hereafter, we report the synthesis, crystal structure and luminescence study of a series of homo-lanthanide complexes with general chemical formula $\left[\mathrm{Ln}(\mathrm{phen})_{2}\left(\mathrm{NO}_{3}\right)_{3}\right]$ $(\operatorname{Ln}=\operatorname{Sm}(\mathbf{1}), \mathrm{Tb}(\mathbf{2}), \mathrm{Nd}(\mathbf{3}), \mathrm{Eu}(\mathbf{4}), \mathrm{Ho}(\mathbf{5})$ and $\mathrm{Y}(\mathbf{6}))$, and of two series of molecular alloys with general chemical formula $\left[\mathrm{Tb}_{1-x} \mathrm{Eu}_{x}(\text { phen })_{2}\left(\mathrm{NO}_{3}\right)_{3}\right]$ and $\left[\mathrm{Tb}_{1-x} \mathrm{Gd}_{x}(\text { phen })_{2}\left(\mathrm{NO}_{3}\right)_{3}\right]$ with $0 \leq x \leq 1$

\section{EXPERIMENTAL}

All reagents were analytical grade and used without further purification.

\section{SEM and EDS}

Scanning Electronic Microscopy (SEM) and Energy-Dispersive Spectroscopy (EDS) measurements have been performed with a Hitachi TM-1000 Tabletop Microscope version 02.11 (Hitachi High-Technologies, Corporation, Tokyo, Japan) with EDS analysis system (SwiftED-TM, Oxford Instruments Link INCA). All EDS measurements were performed several times on several particles in order to insure reproducibility and to confirm powders chemical homogeneity.

\section{Infra-red spectroscopy}

IR spectra were measured with a Perkin Elmer Spectrum II Model FT-IR spectrophotometer using ATR method in the range of $4000-400 \mathrm{~cm}^{-1}$, with a resolution of $4 \mathrm{~cm}^{-1}$ at room-temperature. The IR spectra complexes are similar, so only IR spectrum of complex $\mathbf{1}$ is discussed (Figure S1), It shows characteristic bands of coordinated phen. The 
$v(\mathrm{C}-\mathrm{H})$ stretching vibrations appear at $2923 \mathrm{~cm}^{-1}$, and characteristic $\delta(\mathrm{C}-\mathrm{H})$ out of plane bending vibration are seen at 723 and $841 \mathrm{~cm}^{-1}$, while $\delta(\mathrm{C}-\mathrm{H})$ in the plane bending is observed at $1030 \mathrm{~cm}^{-1}$. The $v(\mathrm{C}=\mathrm{C})$ stretching vibrations (aromatic) appears at $1463 \mathrm{~cm}^{-1}$, and the $v(\mathrm{C}=\mathrm{N})$ stretching vibrations are observed at $1626 \mathrm{~cm}^{-1} \cdot{ }^{[39-40]}$ Typical absorption peaks of coordinated nitrates are observed at $1031 \mathrm{~cm}^{-1}, 1293 \mathrm{~cm}^{-1}$ and $1464 \mathrm{~cm}^{-1}$ and correspond to N-O stretching modes. Weak bands appear at lower wavenumbers around 418 and $416 \mathrm{~cm}^{-1}$, they are assigned to $v(\mathrm{M}-\mathrm{N})$ et $v(\mathrm{M}-\mathrm{O})$ stretching modes, confirming the coordination mode of phen and nitrates groups, respectively. ${ }^{[41]}$

\section{Powder X-ray diffraction}

Powder X-ray diffraction diagrams were recorded on a Panalytical X-Pert Pro diffractometer equipped with an $X^{\prime}$ Celerator detector. Typical measurements conditions were $45 \mathrm{kV}, 40 \mathrm{~mA}$ for $\mathrm{Cu} \mathrm{K}_{\alpha}$ radiation $(\lambda=1.542 \AA)$ in $\theta / \theta$ mode. Simulated diagram was produced using Powdercell and WinPLOTR programs ${ }^{[42-44]}$ on the basis of $\left[\mathrm{Sm}(\mathrm{phen})_{2}\left(\mathrm{NO}_{3}\right)_{3}\right]$ (1) crystal structure.

\section{Thermal analyses}

Thermo-gravimetric and thermo-differential analyses (TG/TD) were carried out in platinum crucibles from room-temperature to $1000^{\circ} \mathrm{C}$ under nitrogen atmosphere with heating rate of $5^{\circ} \mathrm{C} \cdot \mathrm{min}^{-1}$, using a Perkin-Elmer Pyris-Diamond thermal analyzer. At the end of the experiments, the compounds were maintained for $1 \mathrm{~h}$ at $1000^{\circ} \mathrm{C}$ under synthetic air in order to insure complete combustion. All complexes exhibit similar thermal behaviors. Therefore, herein only complex $\mathbf{1}$ is discussed (Figure S2). The TG/TD experiments confirm the absence of coordination solvent molecules in the crystal structure. The complex $\mathbf{1}$ shows a thermal stability up to $290^{\circ} \mathrm{C}$ then exhibits one step of weight loss (observed weight loss is $78.89 \%$ - 
calcd. $78.44 \%)$ that lead to samarium oxide $\left(\mathrm{Sm}_{2} \mathrm{O}_{3}\right)$ at $420^{\circ} \mathrm{C}$. This quite significant thermal stability constitutes an asset as far as technological applications would be targeted.

\section{Optical measurements}

Excitation and emission spectra were recorded in the solid-state at room-temperature on a Horiba Jobin-Yvon Fluorolog-III fluorescence spectrometer with a continuous Xe lamp $(450 \mathrm{~W})$ equipped with an UV-Vis photomultiplier (PMT Hamamatsu R928, range $=190-860 \mathrm{~nm}$ ) and an infrared-photodiode cooled by liquid nitrogen (InGaAs, range $=800-1600 \mathrm{~nm})$. Quantum yields were measured using an integrating sphere from Jobin-Yvon by the following formula: $\Phi=\left(\mathrm{E}_{\mathrm{c}}-\mathrm{E}_{\mathrm{a}}\right) /\left(\mathrm{L}_{\mathrm{a}}-\mathrm{L}_{\mathrm{c}}\right)\left(\mathrm{E}_{\mathrm{c}}\right.$ and $\mathrm{L}_{\mathrm{c}}$ are the integrated emission spectrum and the absorption at the excitation wavelength of the sample, while $\mathrm{E}_{\mathrm{a}}$ and $\mathrm{L}_{\mathrm{a}}$ are the integrated "blank" emission spectrum and "blank" absorption, respectively). Longest luminescence decays $(\tau>10 \mu \mathrm{s})$ have been measured at room-temperature using this apparatus with a Xenon flash lamp (phosphorescence mode). Shortest luminescence decays ( $\tau<10 \mu \mathrm{s}$ ) were measured directly with the fluorescence spectrometer coupled with an additional TCSPC module (Time-Correlated-Single-Photon-Counting) and a $320 \mathrm{~nm}$ pulsed Delta-Diode. Emission/excitation spectra, quantum yields and luminescence lifetimes recordings were performed on powder samples introduced in cylindrical quartz cells of $2.4 \mathrm{~cm}$ height and $0.7 \mathrm{~cm}$ diameter placed inside the integrating sphere or on powder samples pasted on copper plates with silver glue. Luminescence of the Y-based microcrystalline powder has been measured at $77 \mathrm{~K}$. The Y-based compound was introduced in a quartz capillary tube, which was placed inside a small Dewar that contained liquid nitrogen. Quantum yields and luminescence decays are averages of two or three independent determinations.

Comparative solid-state luminescent spectra have been measured on the same Horiba Jobin-Yvon Fluorolog-III fluorescence spectrometer on powders samples shaped as pellets. 
Spectra were recorded between $450 \mathrm{~nm}$ and $725 \mathrm{~nm}$ under identical operating conditions and without turning the lamp off to ensure a valid comparison between the emission spectra.

Appropriate filters were used to remove the residual excitation laser light, the Rayleigh scattered light and associated harmonics from spectra. All spectra were corrected for the instrumental response function.

UV-visible absorption spectra have been recorded in the solid-state on a Perkin-Elmer Lambda $650 \mathrm{UV}$-vis spectrophotometer equipped with a $60 \mathrm{~mm}$ integrating sphere.

Luminance of the samples expressed in $\mathrm{Cd} \cdot \mathrm{m}^{-2}$ have been measured with a Gigahertz-Optik X1-1 optometer with an integration time of $200 \mathrm{~ms}$ on $1.5 \mathrm{~cm}^{2}$ pellets under UV irradiation $\left(\lambda_{\text {exc }}=312 \mathrm{~nm}\right)$. The intensity of the UV flux at sample location, 0.49(1) $\mathrm{mW} . \mathrm{cm}^{-2}$, has been measured with a VilberLourmat VLX-3W radiometer. $\left[\mathrm{Tb}_{2}(\mathrm{bdc})_{3} \cdot 4 \mathrm{H}_{2} \mathrm{O}\right]_{\infty}$, where $\mathrm{bdc}^{2-}$ stands for terephthalate, was used as a standard. Its luminance is $99(1) \mathrm{Cd} \cdot \mathrm{m}^{-2}$ under these operating conditions $\left(\lambda_{\text {exc }}=312 \mathrm{~nm}\right.$; flux $\left.=0.49(1) \mathrm{mW} \cdot \mathrm{cm}^{-2}\right) .^{[45]}$

The CIE (Commission Internationale de l'Eclairage) (x, y) emission color coordinates $^{[46-47]}$ were obtained using a MSU-003 colorimeter (Majantys) with the PhotonProbe 1.6.0 Software (Majantys). Color measurements: $2^{\circ}$, CIE 1931, step $5 \mathrm{~nm}$, under $312 \mathrm{~nm} \quad \mathrm{UV}$ light. $\mathrm{X}=k \times \int_{380 \mathrm{~nm}}^{780 \mathrm{~nm}} I_{\lambda} \times x_{\lambda}, \quad \mathrm{Y}=k \times \int_{380 \mathrm{~nm}}^{780 \mathrm{~nm}} I_{\lambda} \times y_{\lambda} \quad$ and $\quad \mathrm{Z}=k \times$ $\int_{380 \mathrm{~nm}}^{780 \mathrm{~nm}} I_{\lambda} \times z_{\lambda}$ with $\mathrm{k}$ constant for the measurement system, $\mathrm{I} \lambda$ sample spectrum intensity wavelength depending, $\mathrm{x} \lambda, \mathrm{y} \lambda, \mathrm{z} \lambda$ trichromatic values $\mathrm{x}=\mathrm{X} /(\mathrm{X}+\mathrm{Y}+\mathrm{Z}), \mathrm{y}=\mathrm{Y} /(\mathrm{X}+\mathrm{Y}+\mathrm{Z})$ and $\mathrm{z}=\mathrm{Z} /(\mathrm{X}+\mathrm{Y}+\mathrm{Z})$. Mean $\mathrm{xyz}$ values are given for each sample, which act as light sources (luminescent samples). Standards from Phosphor Technology used, calibrated at $312 \mathrm{~nm}$ : red phosphor $\mathrm{Gd}_{2} \mathrm{O}_{2} \mathrm{~S}: \mathrm{Eu}(\mathrm{x}=0.667, \mathrm{y}=0.330)$ and green phosphor $\mathrm{Gd}_{2} \mathrm{O}_{2} \mathrm{~S}: \mathrm{Tb}(\mathrm{x}=0.328$, $\mathrm{y}=0.537)$ 


\section{Synthesis of the complexes as single-crystals}

The complexes were obtained by slow diffusion in thin glass tubes, by reaction of $0.02 \mathrm{mmol}$ of $\mathrm{Ln}\left(\mathrm{NO}_{3}\right)_{3} \cdot 6 \mathrm{H}_{2} \mathrm{O}(\mathrm{Ln}=\mathrm{Sm}(\mathbf{1}), \mathrm{Tb}(\mathbf{2}))$ in $1 \mathrm{~mL}$ of methanol with $0.02 \mathrm{mmol}$ of 1,10-phenanthroline in $1 \mathrm{~mL}$ of THF. Transparent single crystals appeared after 15 days. They were collected, washed with ethanol and dried in air. FT-IR $\left(\mathrm{cm}^{-1}\right)$ of $\mathbf{1}$ and $\mathbf{2}$ are similar: 3064 (vw), 2923 (w), 2854 (w), 1626 (w), 1577 (w), 1464 (vs), 1418 (s), 1290 (s), $1219(\mathrm{~m})$, 1104 (w), 1030 (s), 863 (m), 841 (s), 813 (m), 762 (m), 731 (m), 722 (vs), 639 (m), 553 (vw), $512(\mathrm{vw}), 474(\mathrm{vw}), 415(\mathrm{~s})$.

\section{Crystal structure}

The dimensions of the single-crystal used for the crystal structure determinations, were $0.40 \times 0.25 \times 0.19 \mathrm{~mm}^{3}$ for $\mathbf{1}$ and $0.56 \times 0.27 \times 0.21 \mathrm{~mm}^{3}$ for 2 . The reflection intensities were collected on a Bruker D8 Venture diffractometer equipped with a PHOTON 100 CMOS area detector, at $150 \mathrm{~K}$.

Absorption corrections were performed on the basis of multiple scans. Crystal structures were solved using direct methods with the program SIR-97 $7^{[48]}$ and refined with full matrix least-squares methods based on $\mathrm{F}^{2}{ }^{[48]}$ by using the WinGX program. ${ }^{[49-50]}$ All non-hydrogen atoms were refined anisotropically using the SHELXL program. ${ }^{[51]}$ Hydrogen atoms were located at ideal positions. Crystal and final structural refinement data are listed in Table 1. 
Table 1. Crystal and final structural refinement data for $\left[\mathrm{Sm}(\mathrm{phen})_{2}\left(\mathrm{NO}_{3}\right)_{3}\right](\mathbf{1})$ and $\left[\mathrm{Tb}(\text { phen })_{2}\left(\mathrm{NO}_{3}\right)_{3}\right](\mathbf{2})$.

\begin{tabular}{|c|c|}
\hline 1 & 2 \\
\hline Formula: $\mathrm{C}_{24} \mathrm{H}_{16} \mathrm{~N}_{7} \mathrm{O}_{9} \mathrm{Sm}$ & Formula: $\mathrm{C}_{24} \mathrm{H}_{16} \mathrm{~N}_{7} \mathrm{O}_{9} \mathrm{~Tb}$ \\
\hline Formula weight $\left(\mathrm{g} \cdot \mathrm{mol}^{-1}\right): 696.79$ & Formula weight $\left(\mathrm{g} \cdot \mathrm{mol}^{-1}\right): 705.36$ \\
\hline Crystal system: monoclinic & Crystal system: monoclinic \\
\hline space group: $P 2{ }_{1} / n$ & space group: $P 2_{1} / n$ \\
\hline$a=11.1054(15) \AA$ & $a=11.0462(11) \AA$ \\
\hline$b=17.906(2) \AA$ & $b=17.8589(16) \AA$ \\
\hline$c=12.9863(16) \AA$ & $c=12.9882(13) \AA$ \\
\hline$\beta=100.545(5)^{\circ}$ & $\beta=100.408(4)^{\circ}$ \\
\hline$V=2538.76(55) \AA^{3}$ & $V=2520.06(42) \AA^{3}$ \\
\hline$Z=4$ & $Z=4$ \\
\hline$D_{c}=1.823 \mathrm{~g} \cdot \mathrm{cm}^{-3}$ & $D_{c}=1.8165 \mathrm{~g} \mathrm{~cm}^{-3}$ \\
\hline$T=150(2) \mathrm{K}$ & $T=150(2) \mathrm{K}$ \\
\hline$\mu(\mathrm{Mo}-\mathrm{K} \alpha)=2.382 \mathrm{~cm}^{-1}$ & $\mu(\mathrm{Mo}-\mathrm{K} \alpha)=2.382 \mathrm{~cm}^{-1}$ \\
\hline crystal shape: colorless prism & crystal shape: colorless prism \\
\hline$R 1=0.0235$ & $R l=0.0247$ \\
\hline$w R 2=0.0555$ & $w R 2=0.0629$ \\
\hline$S=1.103$ & $S=1.148$ \\
\hline 5122 reflections & 5286 reflections \\
\hline 370 parameters & 370 parameters \\
\hline
\end{tabular}

\section{Synthesis of the complexes as microcrystalline powders}

Microcrystalline powders of the complexes with chemical formula $\left[\mathrm{Ln}(\mathrm{phen})_{2}\left(\mathrm{NO}_{3}\right)_{3}\right]$ with $\operatorname{Ln}=\operatorname{Sm}(\mathbf{1}), \mathrm{Tb}(\mathbf{2}), \mathrm{Nd}(3), \mathrm{Eu}(4), \mathrm{Ho}(5)$ and $\mathrm{Y}(\mathbf{6})$ were obtained according to the experimental protocol already described by U.P. Singh et al.: ${ }^{[28]}$ To a methanolic solution of $\mathrm{Ln}\left(\mathrm{NO}_{3}\right)_{3} \cdot 6 \mathrm{H}_{2} \mathrm{O}(0.5 \mathrm{mmol}$ in $10 \mathrm{~mL}), 1.0 \mathrm{mmol}$ of 1,10 -phenanthroline in methanol $(10 \mathrm{~mL})$ was added. The resulting solution was stirred for $8 \mathrm{~h}$ and filtered. The filtrate was dried under vacuum. Yield was about $85 \%$.

Powder X-ray diffraction patterns indicate that powders and single-crystals are iso-structural (Figure 1). 


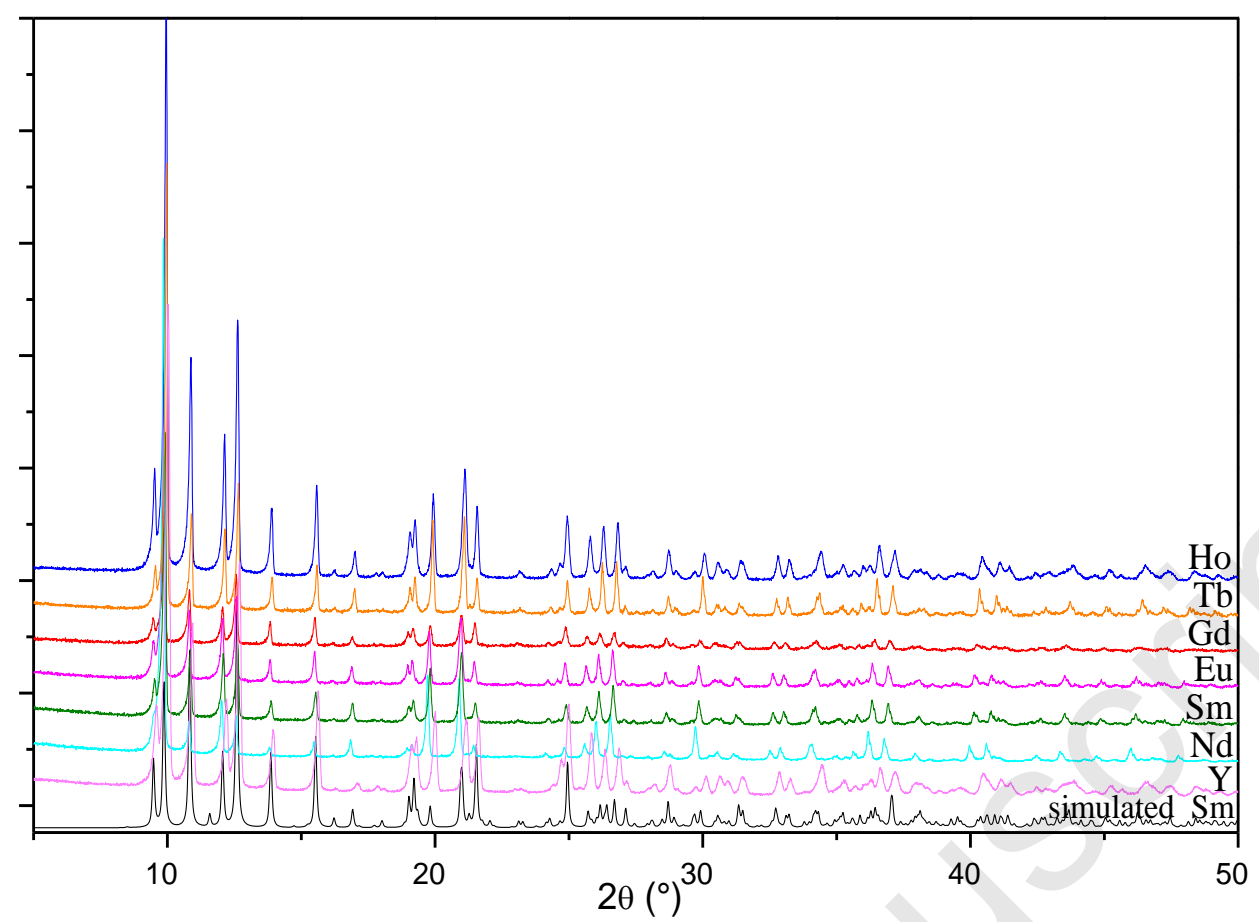

Figure 1: Experimental and simulated powder X-ray diffraction patterns of compounds with general chemical formula $\left[\mathrm{Ln}(\mathrm{phen})_{2}\left(\mathrm{NO}_{3}\right)_{3}\right]$ with $\mathrm{Ln}=\mathrm{Y}, \mathrm{Nd}, \mathrm{Sm}, \mathrm{Eu}, \mathrm{Gd}, \mathrm{Tb}$ and Ho. Simulated powder X-ray diffraction diagram was obtained from the solved crystal structure of the Sm-based complex.

\section{Synthesis of complexes-based molecular alloys.}

Synthesis of the series of molecular alloys of chemical formulas $\left[\mathrm{Tb}_{1-x} \mathrm{Eu}_{x}(\text { phen })_{2}\left(\mathrm{NO}_{3}\right)_{3}\right]$ and $\left[\mathrm{Tb}_{1-x} \mathrm{Gd}_{x}(\text { phen })_{2}\left(\mathrm{NO}_{3}\right)_{3}\right]$ with $0 \leq x \leq 1$ was carried out according to the same experimental protocol as that of the homo-lanthanide microcrystalline powders described above, by replacing lanthanide ions solution by the appropriate mixture of lanthanides nitrates solution. On the basis of their experimental X-ray diffraction diagrams, it has been assumed that they are iso-structural to homo-lanthanide complexes (Figures S3 and S4).

The metal compositions of these complexes-based molecular alloys were measured by EDS (Tables S1 and S2). All the micro-crystalline powders present the same morphology. As a matter of example, a MEB picture of compound $\left[\mathrm{Tb}_{0.1} \mathrm{Gd}_{0.9}(\text { phen })_{2}\left(\mathrm{NO}_{3}\right)_{3}\right]$ is reported in Figure 2. 


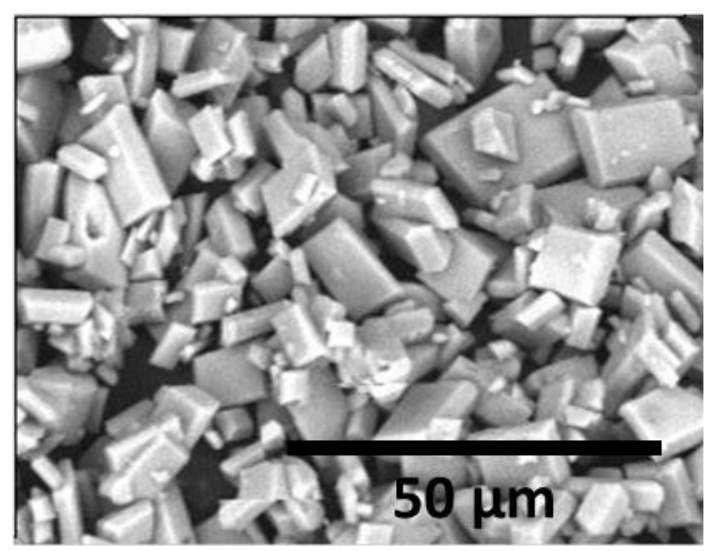

Figure 2. MEB picture of a microcrystalline sample of $\left[\mathrm{Tb}_{0.1} \mathrm{Gd}_{0.9}(\text { phen })_{2}\left(\mathrm{NO}_{3}\right)_{3}\right]$.

\section{Solid state ${ }^{89}$ Y NMR spectroscopy.}

${ }^{89}$ Y CPMAS experiments were performed on a Bruker Avance III 600 (14 T) spectrometer operating at Larmor frequencies of $29.4 \mathrm{MHz}$ and for $600.1 \mathrm{MHz}{ }^{89} \mathrm{Y}$ and ${ }^{1} \mathrm{H}$, respectively. Spectrum was recorded using a low-gamma two channels $7 \mathrm{~mm}$ probe. MAS spinning rate were set to $2 \mathrm{kHz} .{ }^{89} \mathrm{Y}$ CPMAS NMR spectra were acquired using cross-polarization (CP) from ${ }^{1} \mathrm{H}$ using a contact time of $4 \mathrm{~ms}$ (ramped for ${ }^{1} \mathrm{H}$ ), SPINAL64 ${ }^{1} \mathrm{H}$ decoupling during acquisition with a rf field strength of approximately $60 \mathrm{kHz}$, and recycle delay set to $3 \mathrm{~s}$. Chemical shift scales are shown relative to $\mathrm{YCl}_{3}$ in aqueous solution.

\section{RESULTS AND DISCUSSION}

The Sm- (1) and Tb-based (2) complexes are isostructural. Their crystal structure was previously described. ${ }^{[27,33]}$ Therefore, only a brief structural description of complex $\mathbf{1}$ is given hereafter.

The crystal structure is $0 \mathrm{D}$. There is only one independent lanthanide ion in the crystal structure. It is deca-coordinated. Coordination polyhedron can be described as a slightly distorted bi-capped square antiprism as shown in Figure 3. Each Sm(III) ion is surrounded by four $\mathrm{N}$ atoms from two bidentate phen ligands and six $\mathrm{O}$ atoms from three chelating nitrate 
groups which implies that there is neither $\mathrm{C}-\mathrm{H}$ nor $\mathrm{O}-\mathrm{H}$ oscillators in the first coordination sphere of the lanthanide ions.
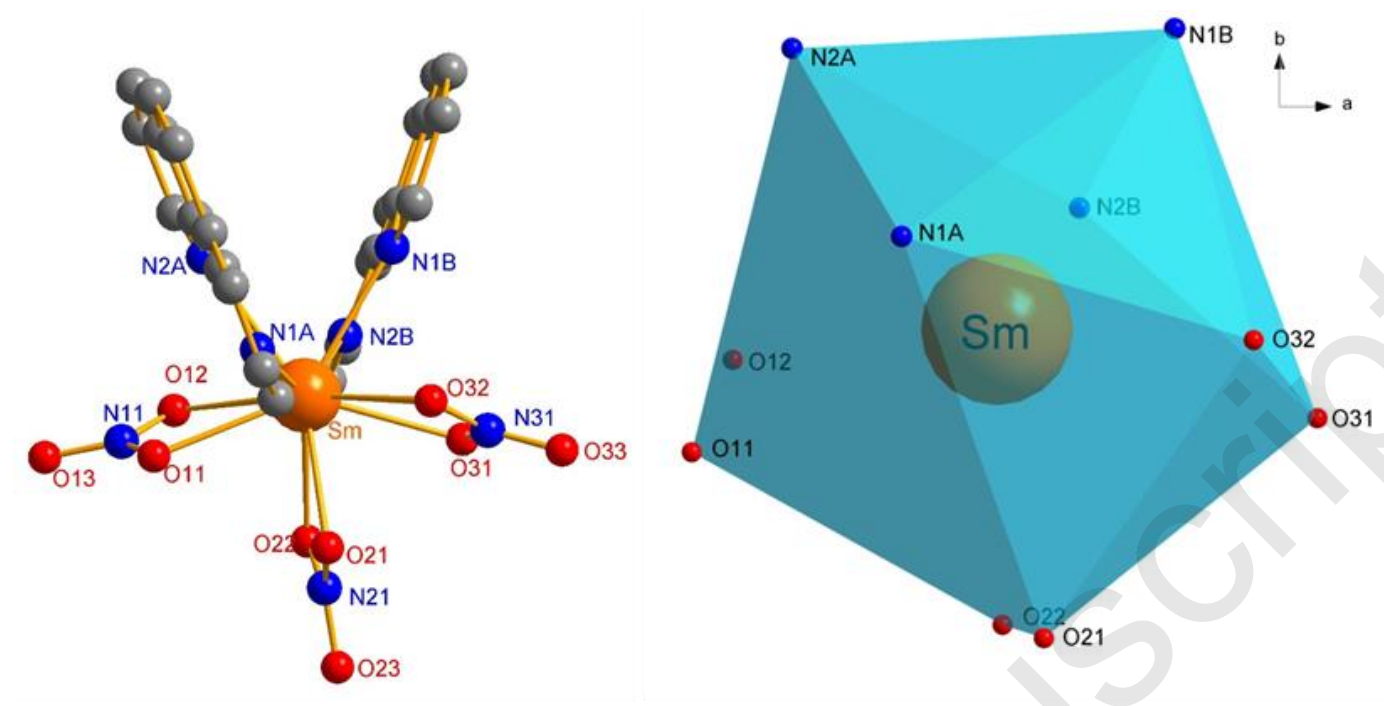

Figure 3. Left: Projection view along the $c$-axis of an asymmetric unit of 1. Right: coordination polyhedron of the $\mathrm{Sm}^{3+}$ ion. All hydrogen atoms have been omitted for clarity.

Ln-N bond lengths vary between 2.55(3) and 2.62(2) $\AA$ and the Ln-O bond distances vary from $2.50(3)$ to $2.54(2) \AA$. Some bond lengths and angles of interest are listed in Table S3. In the crystal packing, the Sm-Sm inter-metallic distances vary between $8.19 \AA$ and $13.52 \AA$ (Figure 4). A given lanthanide complex is surrounded by 6 closest neighbors (from $8.19 \AA$ to $10.39 \AA$ ). Additionally, because the metallic ions distribution in the crystal packing is quite isotropic, the mean inter-metallic distance can be estimated by the rough model that has already been described elsewhere. ${ }^{[52]}$ This model assumes that the volume "occupied" by a lanthanide ion is equal to the unit cell volume $\left(2538 \AA^{3}\right)$ divided by the metallic content of the unit cell $(Z=4)$, that is, in the present case, $635 \AA^{3}$. This "volume per metal", $V$, is then assimilated to the volume of a virtual sphere with radius $r=\sqrt[3]{\frac{3 V}{4 \pi}}(r=5.33 \AA$ here $)$. This calculation allows the estimation of the mean inter-metallic distance: $d=2 r=10.66 \AA$. It is 
noticeable that this mean distance is greater than $10 \AA$ that is the inter-metallic distance above which the inter-metallic energy transfers are usually expected to be less efficient. ${ }^{[53-55]}$

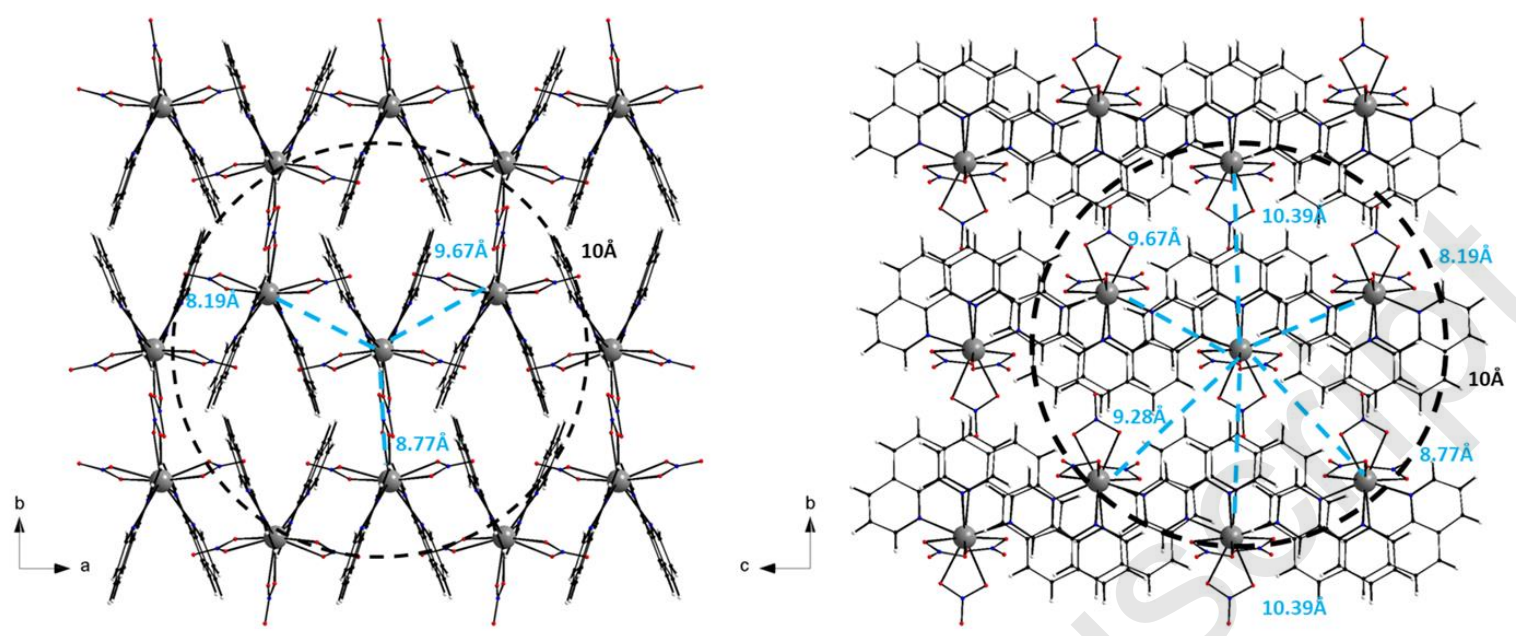

Figure 4. Projection views along the $c$-axis (left) and the $a$-axis (right) of the crystal packing of 1 (all hydrogen atoms have been omitted for clarity). Broken-line circles symbolize the projection of a $10 \AA$ radius sphere centered on a given lanthanide ion. Shortest inter-metallic distances are reported in blue.

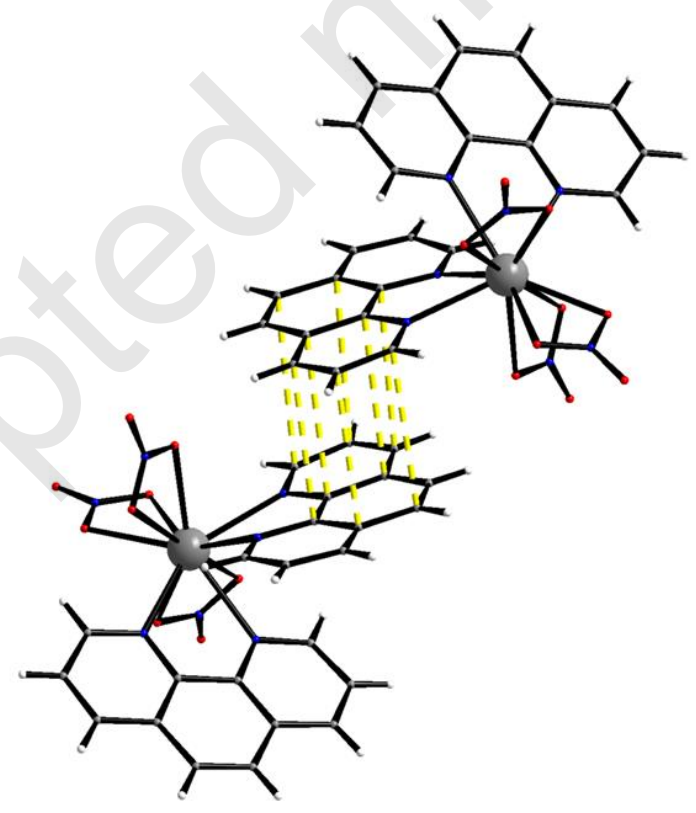

Figure 5. Projection view of two adjacent molecules of complex 1. Yellow broken lines symbolize $\pi-\pi$ interactions.

Along the $a$-axis, the mean distance between two phen ligands from two adjacent molecules is $3.69 \AA$ which suggests significant $\pi-\pi$ stacking interactions between phen ligands 
in the crystal. These inter-molecular interactions insure the stability of the crystal packing (Figure 5). The strength of these interactions is also supported by the thermal analysis (Figure S2) that shows that the compound is stable up to $290{ }^{\circ} \mathrm{C}$. Each molecule interacts with two other molecules via $\pi-\pi$ stacking that form a pseudo-one-dimensional network spreading along the $\vec{a}-\vec{c}$ direction (Figure 6). Importance of these interactions in these systems have already been stressed previously. ${ }^{[25]}$

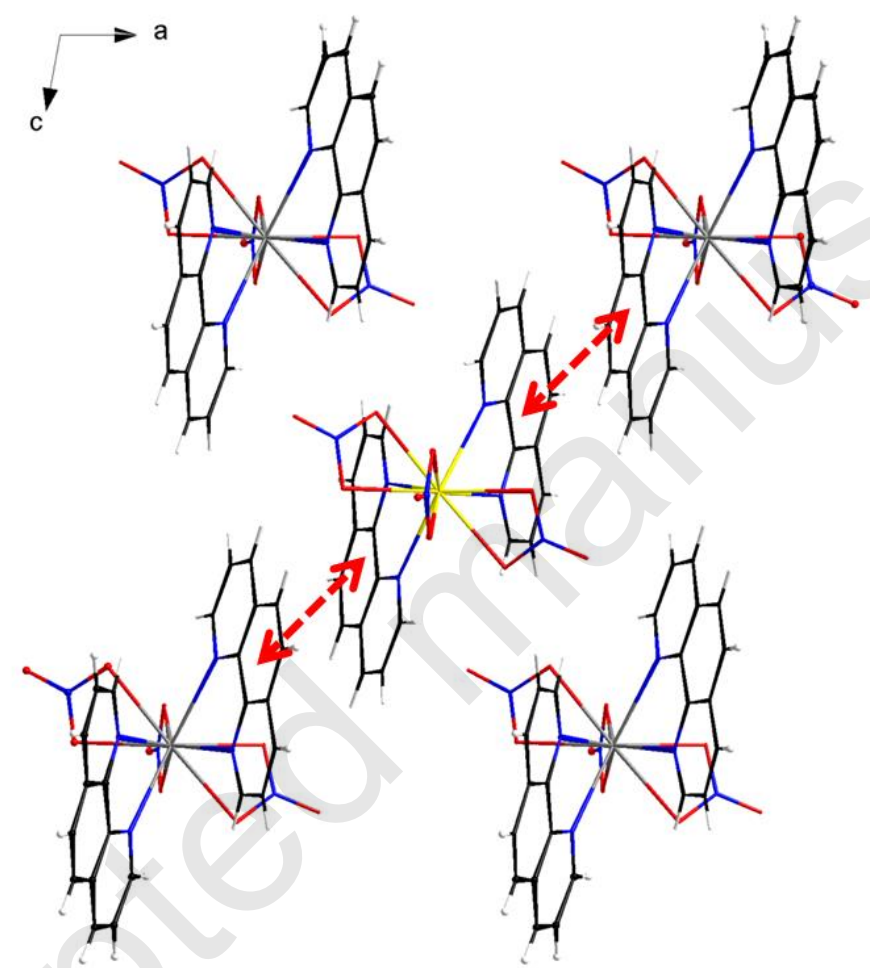

Figure 6. Projection view along the $b$-axis of the crystal packing of complex 1. Red broken double arrows symbolize $\pi$-stacking interactions.

It is also noticeable that this crystal structure presents neither crystallization nor coordination solvent molecules as confirmed by thermal analysis (Figure S2). 


\section{Photoluminescence properties of the complexes.}

Excitation and emission spectra have been recorded for all the six compounds (Figures 7-12). In any case, excitation spectrum presents a broad band centered at $329 \mathrm{~nm}$ that can be assigned to the ${ }^{1} \pi \rightarrow{ }^{1} \pi^{*} \beta^{3} \pi^{*}$ transitions of the ligand which indicates an efficient "antenna effect". ${ }^{[15]}$

Emission spectra of complex 1 in both the visible and the IR regions were recorded upon $329 \mathrm{~nm}$ excitation wavelength (Figure 7). In the visible region, five emission bands, centered at 561, 595-601, 647.5, 709 and $781 \mathrm{~nm}$, are observed. They can be attributed to ${ }^{4} \mathrm{G}_{5 / 2} \rightarrow{ }^{6} \mathrm{H}_{5 / 2},{ }^{6} \mathrm{H}_{7 / 2},{ }^{6} \mathrm{H}_{9 / 2},{ }^{6} \mathrm{H}_{11 / 2},{ }^{6} \mathrm{H}_{13 / 2}$ transitions of $\mathrm{Sm}^{3+}$ ion, respectively. ${ }^{[14,}{ }^{56]}$ The ${ }^{4} \mathrm{G}_{5 / 2} \rightarrow{ }^{6} \mathrm{H}_{9 / 2}$ emission, at $647.5 \mathrm{~nm}$, is the most prominent and induces an orange-red light emission with colorimetric coordinates $(0.596,0.363)$. The emission spectrum of complex 1 in the near-infrared region presents five typical emission bands of $\mathrm{Sm}^{3+}$ at $880,889,945$, 1023, $1162 \mathrm{~nm}$ that can be assigned to ${ }^{4} \mathrm{G}_{5 / 2} \rightarrow{ }^{6} \mathrm{~F}_{1 / 2},{ }^{6} \mathrm{~F}_{3 / 2},{ }^{6} \mathrm{~F}_{5 / 2},{ }^{6} \mathrm{~F}_{7 / 2},{ }^{6} \mathrm{~F}_{9 / 2}$ transitions respectively. ${ }^{[56]}$

The excitation spectra of complex 1 that were recorded at room-temperature, and monitored at $647.5 \mathrm{~nm}$ (Figure 7 top for visible) or $945 \mathrm{~nm}$ (Figure 7 bottom for IR), show a ligand broad band centered at $329 \mathrm{~nm}$ attributed to the excited levels of the ligands and five weak sharp $4 \mathrm{f}-4 \mathrm{f}$ absorption peaks that can be assigned to the ${ }^{6} \mathrm{H}_{5 / 2} \rightarrow{ }^{6} \mathrm{P}_{3 / 2},{ }^{4} \mathrm{G}_{9 / 2},{ }^{4} \mathrm{I}_{13 / 2},{ }^{4} \mathrm{G}_{7 / 2}$ and ${ }^{4} \mathrm{~F}_{3 / 2}(405-535 \mathrm{~nm})$ transitions of $\mathrm{Sm}^{3+}$ ion.

The overall quantum yield, recorded in the visible region, for this compound is $6.0(4) \%$ and the luminescent life time is 39(2) $\mu$ s. This quite strong quantum yield, for a $\mathrm{Sm}^{3+}$-based coordination compound ${ }^{57-60}$ can be related to the absence of $\mathrm{C}-\mathrm{H}$ and $\mathrm{O}-\mathrm{H}$ vibrators in the coordination sphere of $\mathrm{Sm}^{3+}{ }^{3}$ ions. ${ }^{[14]}$ 

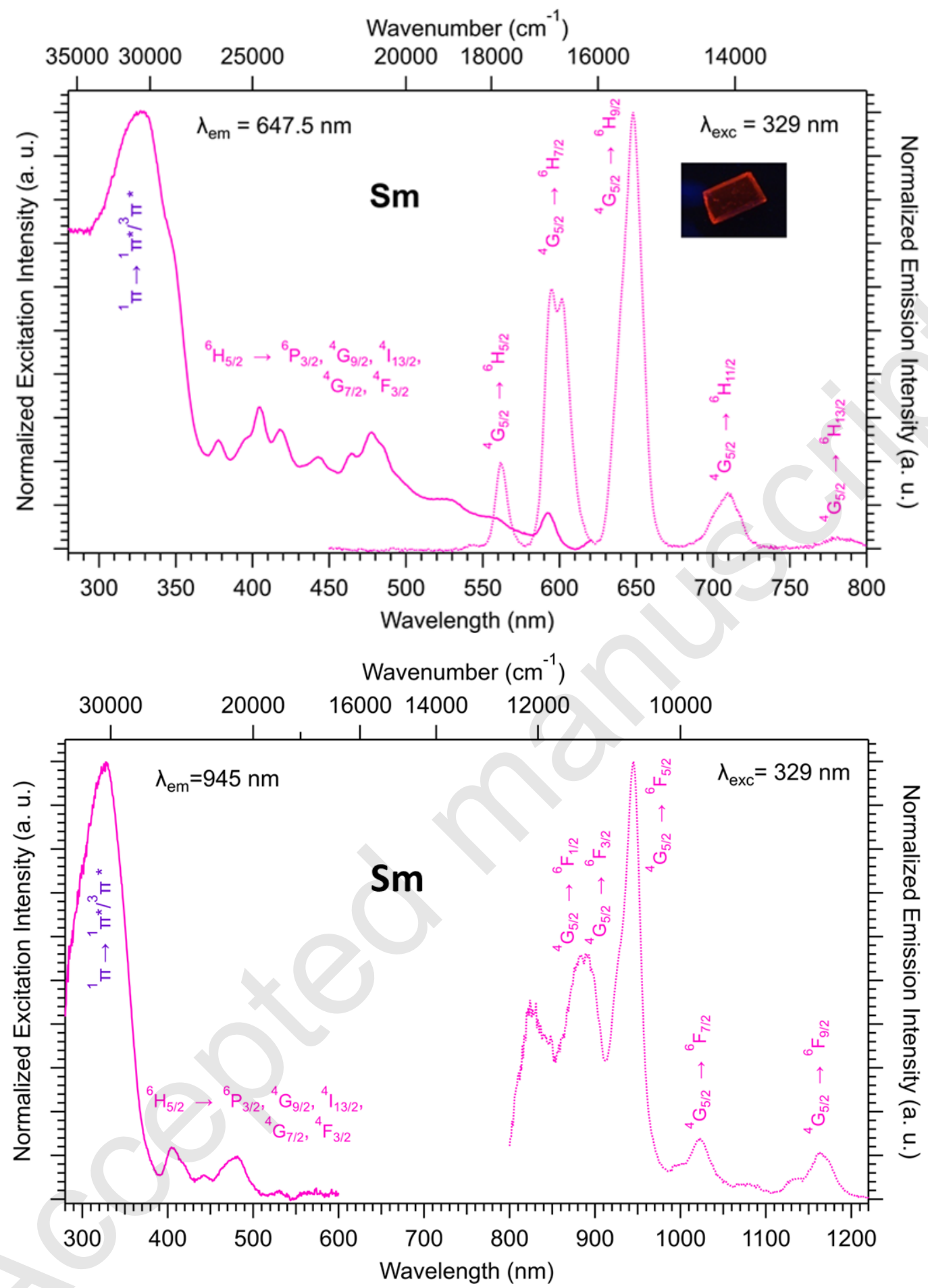

Figure 7. Top: Visible region. Room-temperature solid-state excitation and emission spectra of complex 1. In inset, picture of a single crystal of complex $\mathbf{1}$ under UV irradiation at $\lambda_{\mathrm{exc}}=312 \mathrm{~nm}$.

Bottom: IR region. Room-temperature solid-state excitation and emission spectra of complex 1.

Under excitation at $329 \mathrm{~nm}$, the emission spectrum of complex 2 displays the seven peaks centered at $490,541-548,583,621,649,666$ and $677 \mathrm{~nm}$ that correspond to ${ }^{5} \mathrm{D}_{4} \rightarrow{ }^{7} \mathrm{~F}_{\mathrm{J}}$ 
$(\mathrm{J}=6-0)$ transitions of the $\mathrm{Tb}^{3+}$ ion, respectively (Figure 8). ${ }^{[56,61]}$ The emission peak centered at $541 \mathrm{~nm}\left({ }^{5} \mathrm{D}_{4} \rightarrow{ }^{7} \mathrm{~F}_{5}\right)$ is the strongest one which results in a green emission with colorimetric coordinates $(0.328,0.603)$. The luminescent lifetime for complex 2 is $0.52(1) \mathrm{ms}$ and the overall quantum yield is $87(6) \%$. It must be noticed that despite this quite high overall quantum yield, luminescence intensity of this compound is moderate because of the small absorption coefficient of the ligand $\left(35 \mathrm{Cd} . \mathrm{m}^{-2}\right.$ under $0.49 \mathrm{~mW} . \mathrm{m}^{-2}$ irradiation at $\left.\lambda_{\text {exc }}=312 \mathrm{~nm}\right) .{ }^{[59,62-63]}$

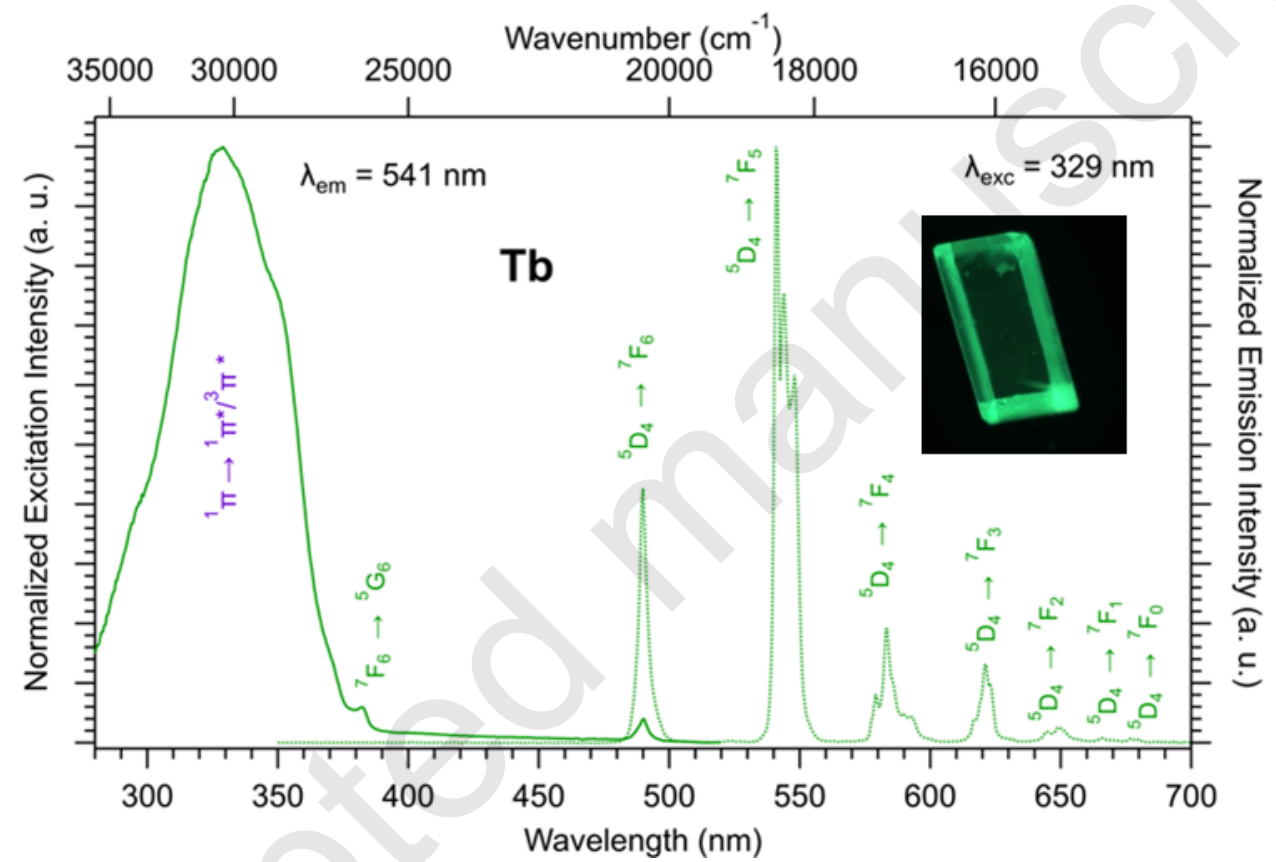

Figure 8. Room-temperature solid-state excitation and emission spectra of complex 2. In inset, picture of a single crystal of complex 2 under UV irradiation at $\lambda_{\text {exc }}=312 \mathrm{~nm}$.

Emission (in the IR region) and excitation spectra of complex 3 were recorded at room-temperature in the solid-state (Figure 9). The emission spectrum of complex $\mathbf{3}$, under excitation at $329 \mathrm{~nm}$, presents three bands centred at 874-909, 1060-1080 and 1312-1400 nm that correspond respectively to ${ }^{4} \mathrm{~F}_{3 / 2} \rightarrow{ }^{4} \mathrm{I}_{9 / 2},{ }^{4} \mathrm{~F}_{3 / 2} \rightarrow{ }^{4} \mathrm{I}_{11 / 2}$ and ${ }^{4} \mathrm{~F}_{3 / 2} \rightarrow{ }^{4} \mathrm{I}_{13 / 2}$ typical transitions of the neodymium ion. The excitation spectrum, monitored at $1060 \mathrm{~nm}$, shows, in addition to the characteristic broad band of phen ligand, the following characteristic transitions of $\mathrm{Nd}^{3+}:\left({ }^{4} \mathrm{I}_{9 / 2} \rightarrow{ }^{4} \mathrm{G}_{11 / 2},{ }^{2} \mathrm{P}_{3 / 2},{ }^{2} \mathrm{D}_{3 / 2},{ }^{2} \mathrm{G}_{9 / 2}\right),\left({ }^{4} \mathrm{I}_{9 / 2} \rightarrow{ }^{4} \mathrm{G}_{9 / 2},{ }^{4} \mathrm{G}_{7 / 2}\right),\left({ }^{4} \mathrm{I}_{9 / 2} \rightarrow{ }^{2} \mathrm{G}_{7 / 2},{ }^{4} \mathrm{G}_{5 / 2}\right),\left({ }^{4} \mathrm{I}_{9 / 2} \rightarrow{ }^{2} \mathrm{H}_{11 / 2}\right)$, 
$\left({ }^{4} \mathrm{I}_{9 / 2} \rightarrow{ }^{4} \mathrm{~F}_{9 / 2}\right),\left({ }^{4} \mathrm{I}_{9 / 2} \rightarrow{ }^{4} \mathrm{~F}_{7 / 2},{ }^{4} \mathrm{~S}_{3 / 2}\right),\left({ }^{4} \mathrm{I}_{9 / 2} \rightarrow{ }^{4} \mathrm{~F}_{5 / 2},{ }^{2} \mathrm{H}_{9 / 2}\right)$ that are respectively centered at 473,529, $584,631,680,742$ and $802 \mathrm{~nm} .{ }^{[64]}$

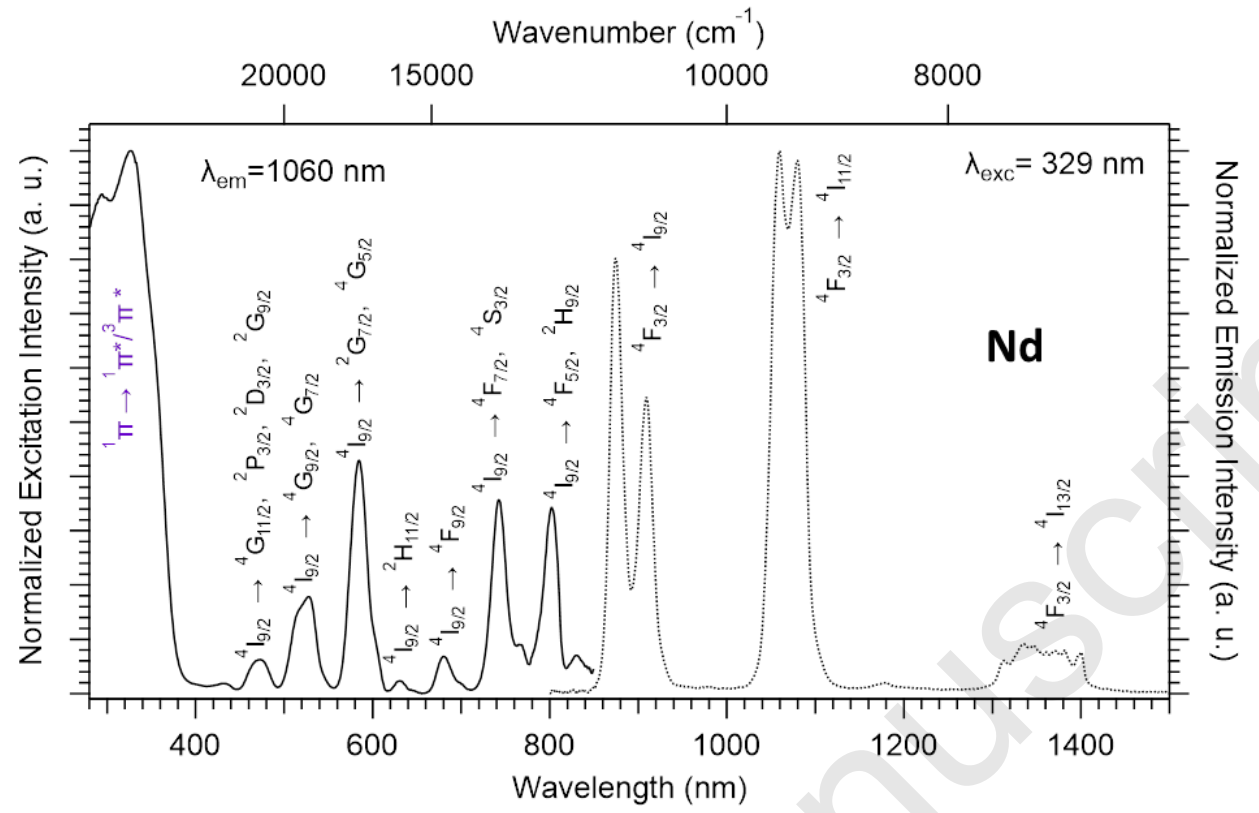

Figure 9. Room-temperature solid-state excitation and emission spectra of complex 3.

Emission and excitation spectra of complex 4 (Figure 10) were collected at room-temperature in the solid-state. Under excitation at $329 \mathrm{~nm}$, the emission spectrum of complex 4 displays six peaks, that can be assigned to the typical transitions of $\mathrm{Eu}^{3+}$ $\left({ }^{5} \mathrm{D}_{0} \rightarrow{ }^{7} \mathrm{~F}_{0-6}\right)$ centered at $576,591,615,649,685,749$ and $830 \mathrm{~nm}$ respectively. ${ }^{[56,65]}$ The excitation spectrum measured for $\lambda_{\mathrm{em}}=615 \mathrm{~nm}$ exhibits, in addition to the strong ${ }^{1} \pi \rightarrow{ }^{1} \pi^{*} /{ }^{3} \pi^{*}$ band, four weak pics centered at $396,416,465$ and $536 \mathrm{~nm}$ that can be attributed respectively to the typical $\mathrm{Eu}^{3+}{ }^{7} \mathrm{~F}_{0} \rightarrow{ }^{5} \mathrm{~L}_{6},{ }^{5} \mathrm{D}_{3-1}$ transitions. The luminescent lifetime has been estimated to $1.05(1) \mathrm{ms}$. The overall quantum yield is close to $100 \%$ but the low absorbance of complex $\mathbf{4}$ doesn't allow its accurate determination. 


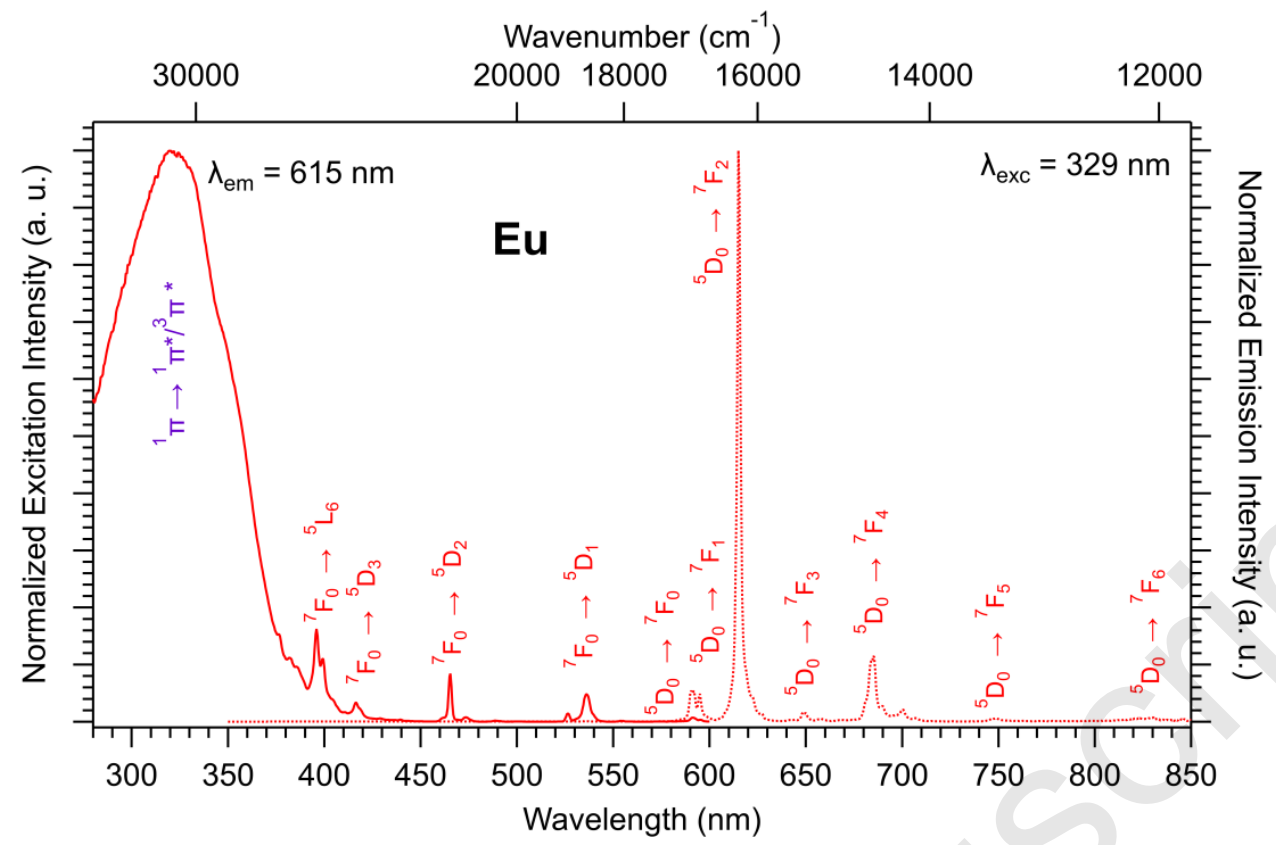

Figure 10. Room-temperature solid-state excitation and emission spectra of complex 4.

Emission and excitation spectra of complex 5 in the UV-vis region are reproduced in Figure 11. They were recorded in the solid-state at room-temperature. The emission spectrum of complex 5 has been recorded by applying $329 \mathrm{~nm}$ excitation wavelength. It shows holmium ions transition ${ }^{5} \mathrm{~F}_{3} \rightarrow{ }^{5} \mathrm{I}_{7}$ and ${ }^{5} \mathrm{~F}_{5} \rightarrow{ }^{5} \mathrm{I}_{8}$ in the area 643-662 nm. Emission spectrum of complex 5, in the IR region, shows the ${ }^{5} \mathrm{~F}_{5} \rightarrow{ }^{5} \mathrm{I}_{7}$ and ${ }^{5} \mathrm{~F}_{4} \rightarrow{ }^{5} \mathrm{I}_{6}$ specific transitions of $\mathrm{Ho}^{3+}$ ion in the IR region. They occur in the range of 960-1020 nm. Excitation spectrum in the IR region of complex 5 shows the typical ${ }^{5} \mathrm{I}_{8} \rightarrow{ }^{5} \mathrm{G}_{5},{ }^{3} \mathrm{G}_{5}$ and ${ }^{5} \mathrm{I}_{8} \rightarrow{ }^{5} \mathrm{~F}_{1},{ }^{3} \mathrm{G}_{8}$ transitions of holmium ions centered at 421 and $454 \mathrm{~nm}$ respectively. ${ }^{[56]}$ 

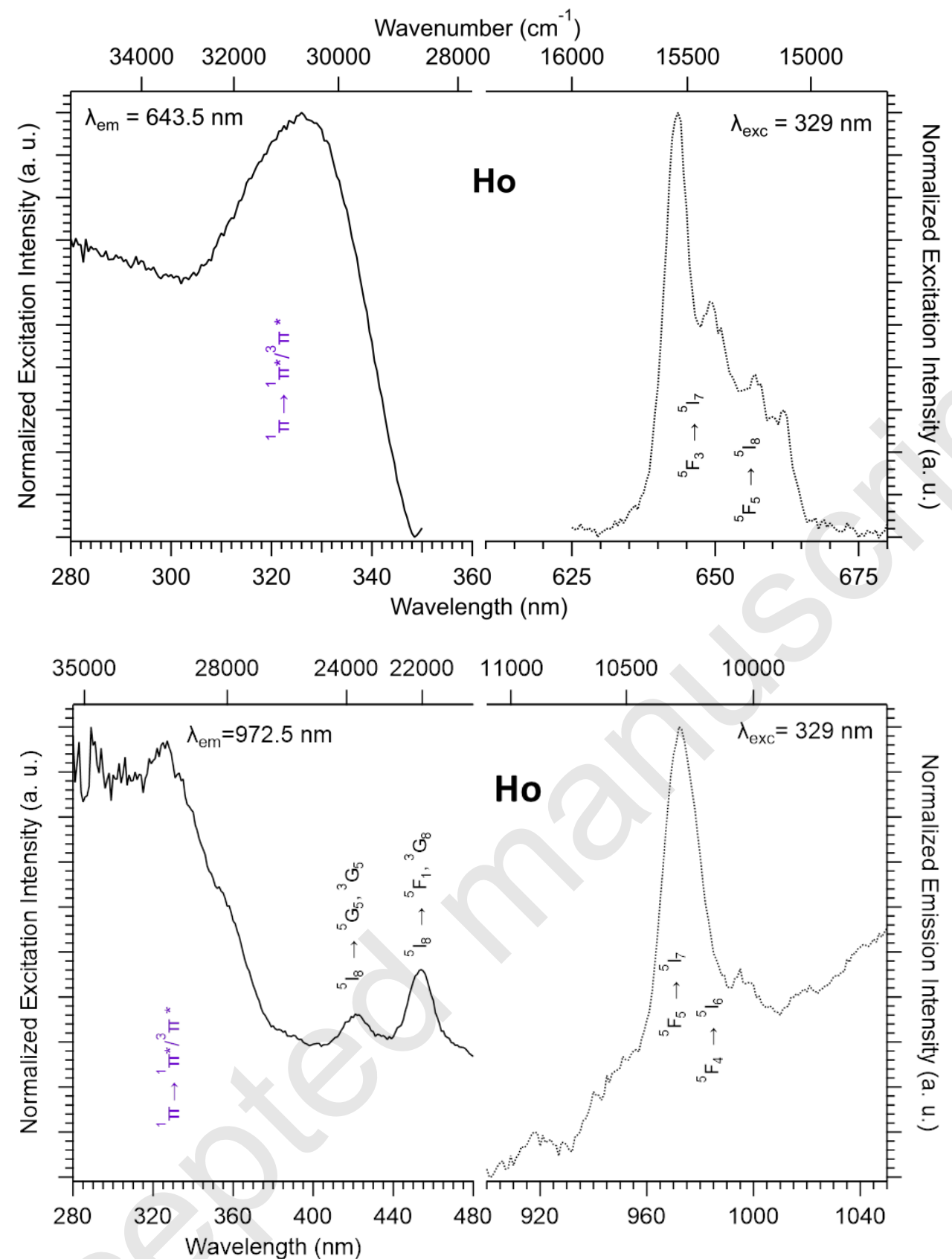

Figure 11. (top - visible region). Room-temperature solid-state excitation and emission spectra of complex 5: (bottom - IR region). Room-temperature solid-state excitation and emission spectra of complex $\mathbf{5}$.

Emission and excitation spectra of complex 6 have been recorded (Figure 12). Because $\mathrm{Y}^{3+}$ is a non-luminescent ion, these spectra show the optical properties of the ligand engaged in this crystal structure. Therefore, both spectra show the intrinsic $\left({ }^{* 1} \pi \rightarrow{ }^{1} \pi^{*} / 3 \pi\right)$ transition of the ligand. It is noticeable that the last absorption edge of this compound is about $375 \mathrm{~nm}\left(26700 \mathrm{~cm}^{-1}\right)$. Obviously, it is not the energy state that is responsible for the excitation 
of the luminescent lanthanide ions since excitation spectra all present a maximum intensity at $329 \mathrm{~nm}\left(30400 \mathrm{~cm}^{-1}\right)$ (Figures 7-11). Usually, the energy of the state that is at the origin of the Ligand-to-Lanthanide energy transfers are estimated by the energy of the first edge of the emission band of an optically non-active lanthanide-based coordination compound. ${ }^{[14]}$ That is, in the present case, $28600 \mathrm{~cm}^{-1}(350 \mathrm{~nm})$.
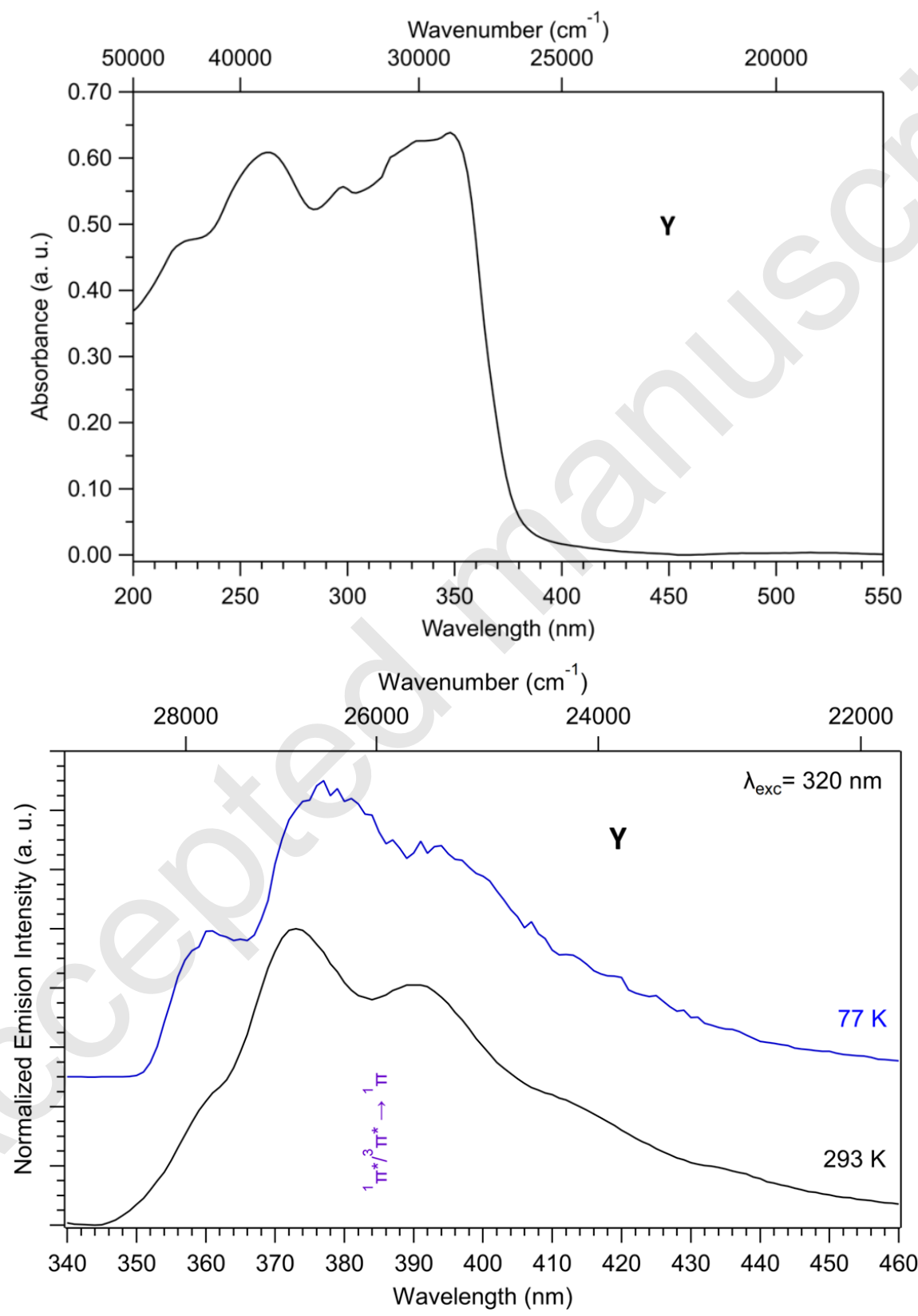

Figure 12. Solid state absorption (top) and emission (bottom) spectra of complex 6: Emission spectra have been recorded at $77 \mathrm{~K}$ and at room-temperature with $\lambda_{\mathrm{exc}}=320 \mathrm{~nm}$. 
This quite intense emission band of the ligand is usually assigned to a ${ }^{3} \pi^{*} \rightarrow{ }^{1} \pi$ phosphorescence. However, in this system, the measured lifetime of the luminescence $\left(\tau_{\mathrm{obs}}=6.1(1) \mathrm{ns}\right)$ is much shorter than what was reported previously for lanthanide-based coordination polymers with carboxylate ligands $\left(\tau_{\text {phospho }}>1 \mathrm{~ms}\right) .{ }^{[63]}$ This suggests that this luminescence band could be attributed to ${ }^{1} \pi^{*} \rightarrow{ }^{1} \pi$ fluorescence and that Ligand-to-Metal energy transfers occur from excited ligand singlet states (see Scheme 1).

It has been shown that a too high energy difference between the ligand feeding state and the lanthanide emissive state is not favorable to high sensitization rate. Of course, energy transfers can be achieved via energy levels that lie higher than the lanthanide emissive level, but in that case, the energy difference between these levels and the ligand feeding level must be important enough for avoiding back-transfers. ${ }^{[66-71]}$

In this system the energy difference between the ligand energy level and the lanthanide emissive levels is around $8200 \mathrm{~cm}^{-1}$ for the Tb-based complex $\left(E\left({ }^{5} \mathrm{D}_{4}\right)=490 \mathrm{~nm}\right.$ or $\left.20400 \mathrm{~cm}^{-1}\right)$ and $11200 \mathrm{~cm}^{-1}$ for the Eu-based one $\left(\mathrm{E}\left({ }^{5} \mathrm{D}_{0}\right)=576 \mathrm{~nm}\right.$ or $\left.17400 \mathrm{~cm}^{-1}\right)$. These high values suggest that Ligand-to-Lanthanide energy transfers imply lanthanide states of higher energy (Scheme 1). For the $\mathrm{Eu}^{3+}$ ions, there are several potential acceptor levels: ${ }^{5} \mathrm{D}_{1}\left(19100 \mathrm{~cm}^{-1}\right),{ }^{5} \mathrm{D}_{2}\left(21500 \mathrm{~cm}^{-1}\right),{ }^{5} \mathrm{D}_{3}\left(24300 \mathrm{~cm}^{-1}\right),{ }^{5} \mathrm{~L}_{6}\left(25300 \mathrm{~cm}^{-1}\right),{ }^{5} \mathrm{G}_{2}\left(26250 \mathrm{~cm}^{-1}\right)$, ${ }^{5} \mathrm{~L}_{7}\left(26400 \mathrm{~cm}^{-1}\right),{ }^{5} \mathrm{G}_{3,4,5,6}\left(26500-26700 \mathrm{~cm}^{-1}\right),{ }^{5} \mathrm{~L}_{8}\left(27300 \mathrm{~cm}^{-1}\right)$ and ${ }^{5} \mathrm{D}_{4}\left(27500 \mathrm{~cm}^{-1}\right) .{ }^{[56,65]}$ Some of them can favor efficient energy transfers without significant back-transfers. On the contrary, for the $\mathrm{Tb}^{3+}$, higher energy levels $\left({ }^{5} \mathrm{D}_{3}\left(26300 \mathrm{~cm}^{-1}\right), \quad{ }^{5} \mathrm{G}_{6}\left(26400 \mathrm{~cm}^{-1}\right)\right.$, ${ }^{5} \mathrm{~L}_{10}\left(27150 \mathrm{~cm}^{-1}\right),{ }^{5} \mathrm{G}_{5}\left(28000 \mathrm{~cm}^{-1}\right),{ }^{5} \mathrm{D}_{2}\left(28150 \mathrm{~cm}^{-1}\right)$ and ${ }^{5} \mathrm{G}_{4}\left(28300 \mathrm{~cm}^{-1}\right)$ lie between $26500 \mathrm{~cm}^{-1}$ and $27500 \mathrm{~cm}^{-1}$ and can induce significant back-transfers.

However it can be noticed that the sensitization efficiency $\left(\eta_{\text {sens }}\right)^{[14]}$ is probably very high for both the Eu- and the Tb-based complexes since their overall quantum yields are very high. 

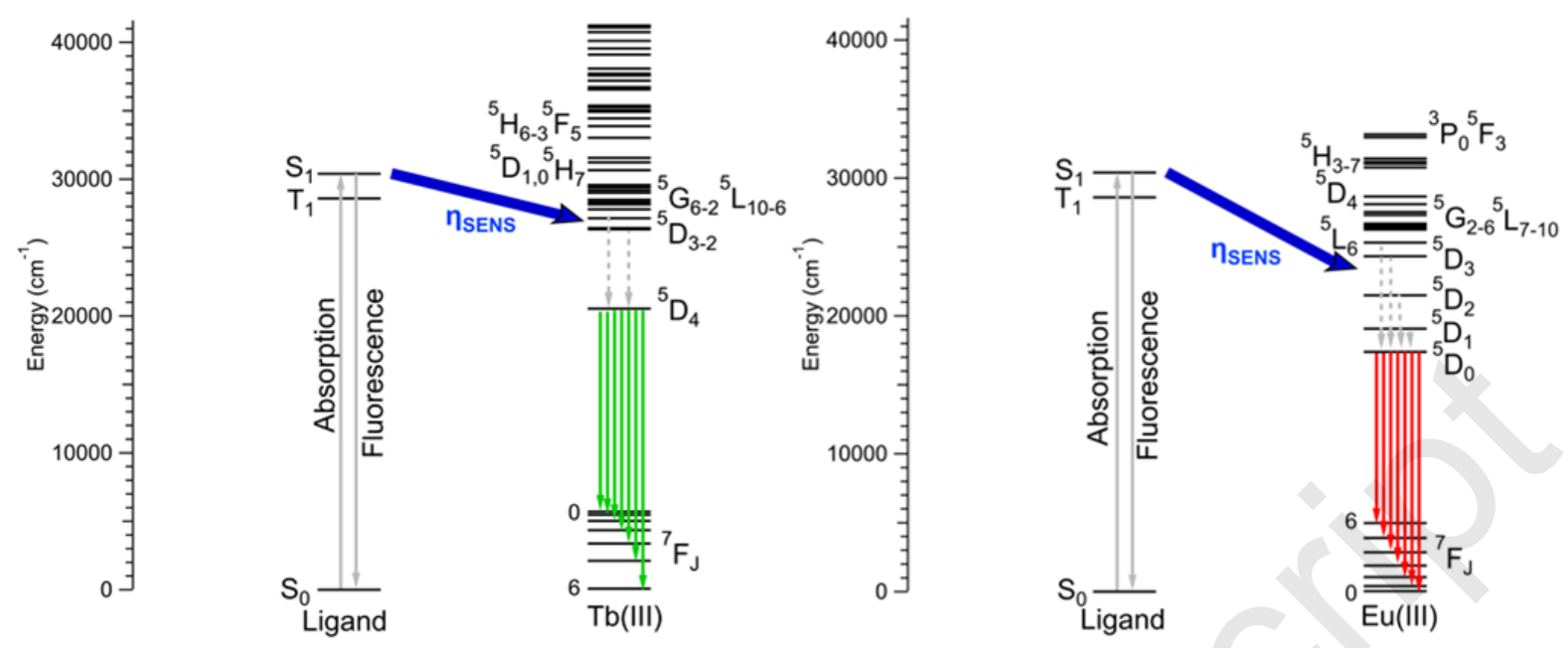

Scheme 1. Schematic representation of the energy states of the ligand and of the lanthanide ions with energy transfer pathways.

This relative location of the energy levels of the ligand and of the lanthanide ions combined with the absence of $\mathrm{O}-\mathrm{H}$ and $\mathrm{C}-\mathrm{H}$ oscillators in the vicinity of the lanthanide ions, that is known for drastically reducing $\mathrm{Eu}^{3+}$ luminescence ${ }^{[14]}$, can explain the very strong luminescence intensity of the $\mathrm{Eu}^{3+}$-based complex as compared to that of the $\mathrm{Tb}^{3+}$-based one. Indeed, contrary to what usually observed, the luminance of the Eu-based complex (111 Cd.m $\mathrm{m}^{-2}$ under $0.49 \mathrm{~mW} \cdot \mathrm{m}^{-2}$ irradiation at $\lambda_{\mathrm{exc}}=312 \mathrm{~nm}$ ) is very significant and much higher than the luminance of the Tb-based one $\left(35 \mathrm{Cd} \cdot \mathrm{m}^{-2}\right.$ under $0.49 \mathrm{~mW} \cdot \mathrm{m}^{-2}$ irradiation at $\left.\lambda_{\mathrm{exc}}=312 \mathrm{~nm}\right)$.

As a summary, characteristic photo-physical values that have been measured are listed in Table 2. On the basis of these interesting results we have undertaken a study of microcrystalline powders of molecular alloys.

Table 2. Summary of the measured photo-physical values of $\left[\mathrm{Ln}(\text { phen })_{2}\left(\mathrm{NO}_{3}\right)_{3}\right]$ complexes with $\mathrm{Ln}=\mathrm{Sm}, \mathrm{Eu}, \mathrm{Tb}$ and $\mathrm{Y}$.

\begin{tabular}{lccc} 
& $\tau_{\text {obs }}$ & $Q_{L n^{3+}}^{\text {Ligand }}(\%)$ & Luminance $\left(\mathrm{Cd} . \mathrm{m}^{-2}\right)$ \\
\hline$\left[\mathrm{Sm}(\text { phen })_{2}\left(\mathrm{NO}_{3}\right)_{3}\right](\mathbf{1})$ & $39(2) \mu \mathrm{s}$ & $6.0(4)$ & - \\
{$\left[\mathrm{Tb}(\text { phen })_{2}\left(\mathrm{NO}_{3}\right)_{3}\right](\mathbf{2})$} & $0.52(1) \mathrm{ms}$ & $87(6)$ & $35(1)$ \\
{$\left[\mathrm{Eu}(\mathrm{phen})_{2}\left(\mathrm{NO}_{3}\right)_{3}\right](\mathbf{4})$} & $1.05(1) \mathrm{ms}$ & $\sim 100$ & $111(5)$ \\
{$\left[\mathrm{Y}(\text { phen })_{2}\left(\mathrm{NO}_{3}\right)_{3}\right](\mathbf{6})$} & $6.1(1) \mathrm{ns}$ & - & - \\
\hline
\end{tabular}


Characterization of the molecular alloys. Photo-physical measurements of $\left[\mathrm{Tb}_{1-x} \mathrm{Eu}_{x}\left(\right.\right.$ phen $\left._{2}\left(\mathrm{NO}_{3}\right)_{3}\right]$ (series 8) and $\left[\mathrm{Tb}_{1-x} \mathrm{Gd}_{x}\left(\right.\right.$ phen $\left._{2}\left(\mathrm{NO}_{3}\right)_{3}\right]($ series 9) with $0 \leq x \leq 1$.

In order to verify if in hetero-lanthanide compounds lanthanide ions are randomly distributed over the metallic sites of the crystal structure we have prepared $\left[\mathrm{Y}_{0.75} \mathrm{Lu}_{0.25}(\text { phen })_{2}\left(\mathrm{NO}_{3}\right)_{3}\right]$ (7) (Figure S5), recorded its ${ }^{89} \mathrm{Y}$ solid-state NMR spectrum and compared it with the one of $\left[\mathrm{Y}(\mathrm{phen})_{2}\left(\mathrm{NO}_{3}\right)_{3}\right]$. This procedure has already been successfully used to demonstrate the "molecular alloy"[16] character (i.e; the statistic distribution of different lanthanide ions in the compound) of hetero-lanthanide-based coordination polymers. ${ }^{[17-19,45]}$ Unfortunately, in the present case, a shift of the peak is observed but it is very small and does not allow for a non-ambiguous conclusion on the local ordering of the lanthanide ions (Figure 13).

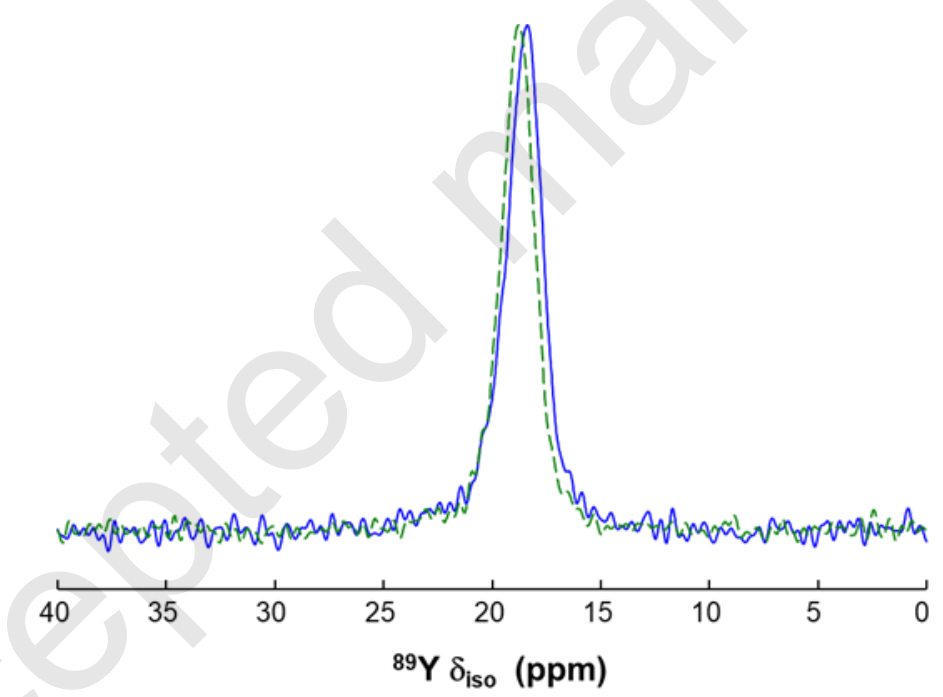

Figure 13. Solid-state CPMAS ${ }^{89} \mathrm{Y}$ NMR spectra of $\left[\mathrm{Y}(\mathrm{phen})_{2}\left(\mathrm{NO}_{3}\right)_{3}\right]$ (6) (solid line) and $\left[\mathrm{Y}_{0.75} \mathrm{Lu}_{0.25}(\mathrm{phen})_{2}\left(\mathrm{NO}_{3}\right)_{3}\right]$ (7) (dashed line).

Therefore, two series of hetero-lanthanide complexes with respective general chemical formula $\left[\mathrm{Tb}_{1-x} \mathrm{Eu}_{x}(\text { phen })_{2}\left(\mathrm{NO}_{3}\right)_{3}\right]$ and $\left[\mathrm{Tb}_{1-x} \mathrm{Gd}_{x}(\text { phen })_{2}\left(\mathrm{NO}_{3}\right)_{3}\right]$ with $0 \leq x \leq 1$ have been prepared. All these compounds are isostructural to $\left[\mathrm{Sm}(\mathrm{phen})_{2}\left(\mathrm{NO}_{3}\right)_{3}\right](\mathbf{1})$ (Figures $\mathrm{S} 3$ and S4). 
Solid-state emission spectra of the compounds that constitute the two series have been recorded under UV irradiation at $329 \mathrm{~nm}$ (Figure 14).

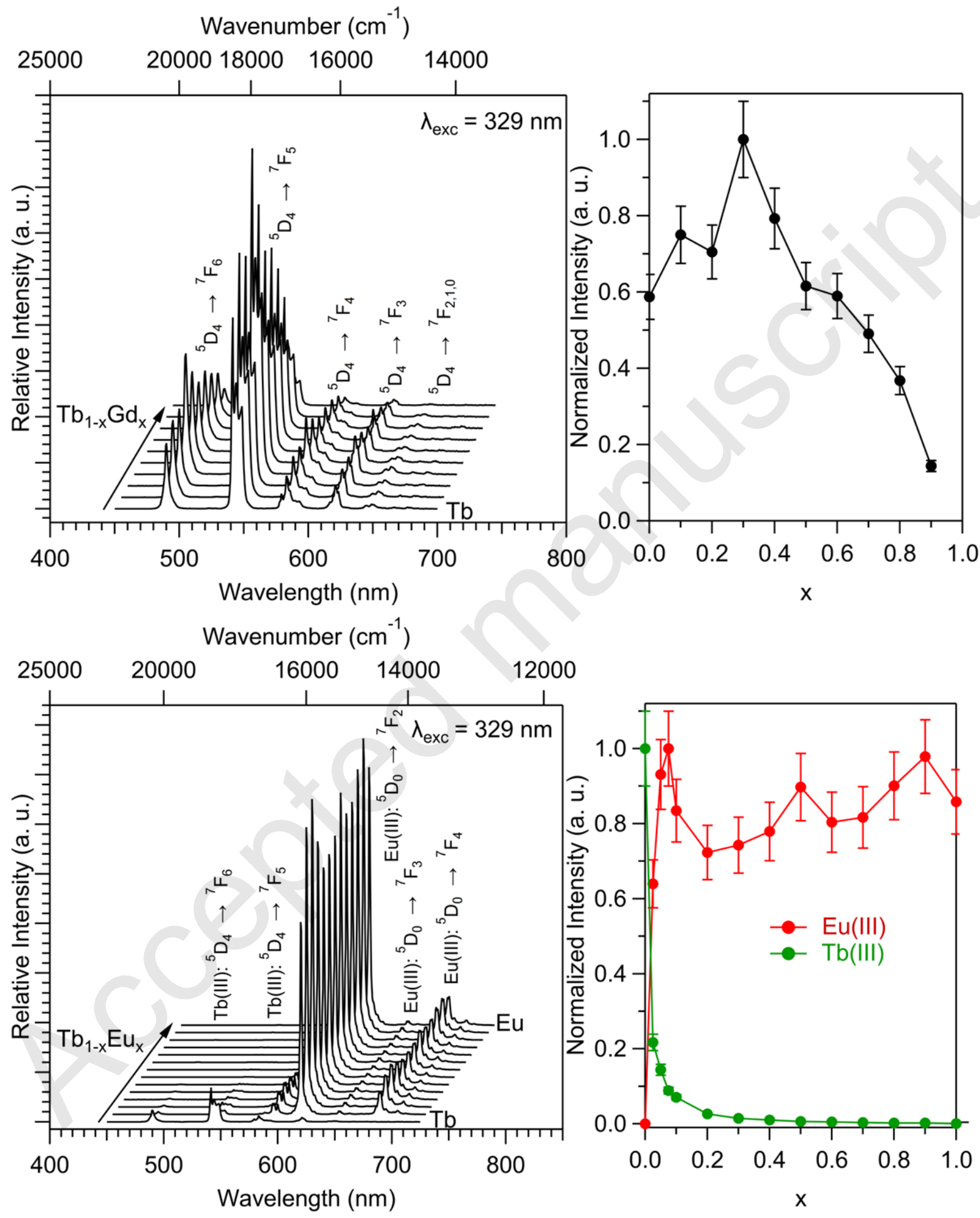

Figure 14. Top left: Solid-state emission spectra of $\left[\mathrm{Tb}_{1-x} \mathrm{Gd}_{x}(\text { phen })_{2}\left(\mathrm{NO}_{3}\right)_{3}\right]$ (series 9) with $0 \leq x \leq 1\left(\lambda_{\text {exc }}=329 \mathrm{~nm}\right)$. Top right: Integrated intensity of the major peak of $\mathrm{Tb}^{3+}$ centered at $541.5 \mathrm{~nm}$ versus $x$. 
Bottom left: Solid-state emission spectra of $\left[\mathrm{Tb}_{1-x} \mathrm{Eu}_{x}(\text { phen })_{2}\left(\mathrm{NO}_{3}\right)_{3}\right]$ (series 8) with $0 \leq x \leq 1$ $\left(\lambda_{\text {exc }}=329 \mathrm{~nm}\right)$. Bottom right: Integrated intensity of the major peaks of $\mathrm{Tb}^{3+}$ centered at $541.5 \mathrm{~nm}$ and of $\mathrm{Eu}^{3+}$ centered at $615 \mathrm{~nm}$ versus $x$.

Emission spectra of the compounds with general chemical formula $\left[\mathrm{Tb}_{1-x} \mathrm{Gd}_{x}(\mathrm{phen})_{2}\left(\mathrm{NO}_{3}\right)_{3}\right]$ with $0 \leq x \leq 1$ show that addition of $\mathrm{Gd}^{3+}$ non-emissive ions provokes a sizeable enhancement of the emission intensity $(+70 \%$ for $x=0.3)$ even for the smallest doping rates $(+20 \%$ for $x=0.1)$. Then, for $x$ varying between 0.3 and 0.6 , emission intensities decrease, because of the $\mathrm{Tb}^{3+}$ ratio decreasing, but remains stronger than that of the pure Tb-based complex $(x=0)$. This behavior was not anticipated because the large inter-metallic distances observed in the crystal structure should induce a small dilution effect for low $x$ values followed by a decrease of the luminescence as the $\mathrm{Tb}^{3+}$ ion content decreases. This unexpected behavior suggests strong inter-metallic energy transfers. It also suggests that these microcrystalline powders are "molecular alloys"[16] and present no segregation of the metals. Indeed, in case of segregation, the luminescence intensity would be expected to be quasi-proportional to $x$.

This findings are confirmed by the emission spectra of the compounds with general chemical formula $\left[\mathrm{Tb}_{1-x} \mathrm{Eu}_{x}(\text { phen })_{2}\left(\mathrm{NO}_{3}\right)_{3}\right]$ with $0 \leq x \leq 1$. Indeed, as shown in Figure 14 , the $\mathrm{Tb}^{3+}$ luminescence abruptly decreases and almost vanishes, which strongly suggests efficient Tb-to-Eu inter-metallic energy transfers. This also confirms the random distribution of the lanthanide ions over the metallic sites of the crystal structure. Indeed, in segregated compounds, inter-metallic energy transfers are weak. ${ }^{[72]}$

In order to quantify these inter-metallic energy transfers, $\mathrm{Tb}^{3+}$ luminescence lifetimes have been measured for compounds $\left[\mathrm{Tb}_{0.8} \mathrm{Eu}_{0.2}(\text { phen })_{2}\left(\mathrm{NO}_{3}\right)_{3}\right] \quad\left(\tau_{\mathrm{Tb}}=\tau_{\mathrm{obs}}=17(1) \mu \mathrm{s}\right.$ and $\left.\tau_{\mathrm{Eu}}=0.99(1) \mathrm{ms}\right)$ and $\left[\mathrm{Tb}_{0.8} \mathrm{Gd}_{0.2}(\text { phen })_{2}\left(\mathrm{NO}_{3}\right)_{3}\right]\left(\tau_{\mathrm{Tb}}=\tau_{0}=0.52(1) \mathrm{ms}\right)$ These luminescence lifetimes of the $\mathrm{Tb}^{3+}$ ion, respectively measured in the presence $\left(\tau_{\mathrm{obs}}\right)$ and in the absence $\left(\tau_{0}\right)$ 
of an acceptor ion are related to inter-metallic energy transfers efficiency ( $\left.\eta_{\mathrm{ET}}\right)$ according to the relationship: ${ }^{[14]}$

$\eta_{E T}=1-\frac{\tau_{o b s}}{\tau_{0}}$

This relationship leads, in the present case, to $\eta_{\mathrm{ET}}=97(1) \%$. This very significant value $^{[45]}$ evidences that there are some efficient inter-metallic energy transfer pathways (Scheme 2). Since molecules are isolated, and transition metal ions quite far from each other, this suggests that inter-metallic energy transfers could be mediated by the $\pi$-stacked phen ligands. This phenomenon has already been invoked for related complexes in literature. ${ }^{[73]}$

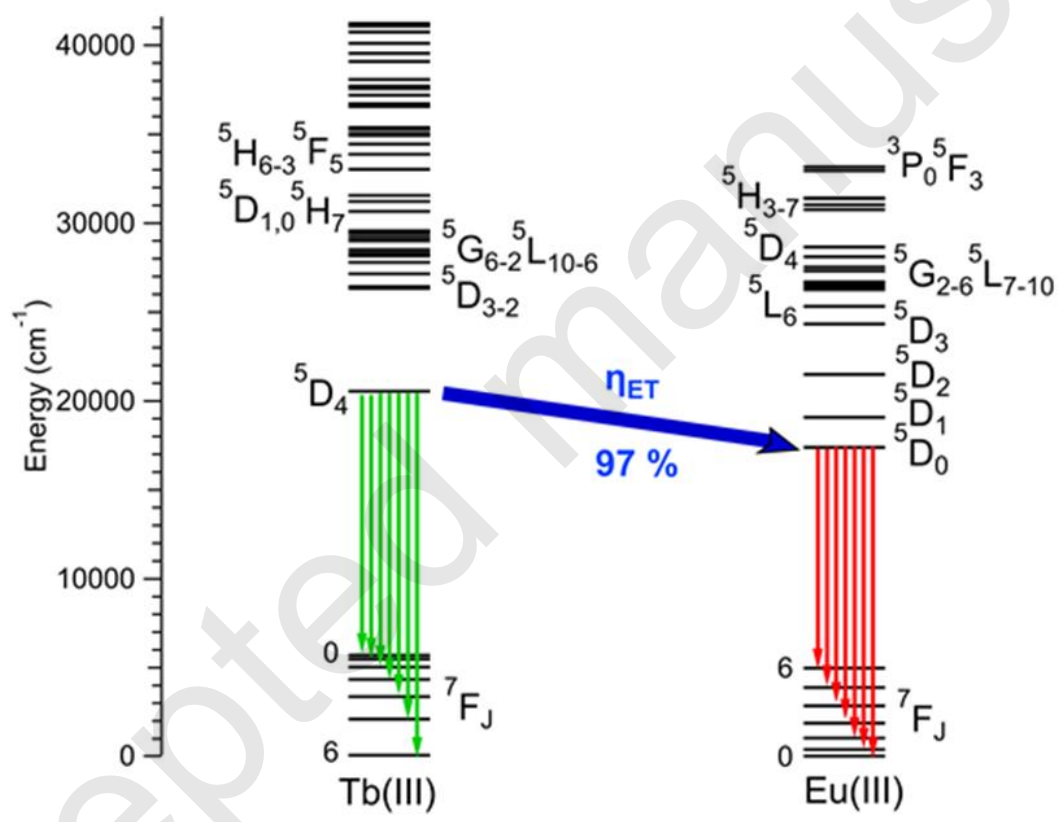

Scheme 2. Schematic representation of the energy transfer pathways that are responsible to $\mathrm{Eu}^{3+}$ and $\mathrm{Tb}^{3+}$-based molecular alloys

\section{CONCLUSION AND OUTLOOK}

This study shows that the use of phen ligand prevents from the presence of solvent molecules coordinated to the lanthanide ions in this series of compounds. It leads to high overall quantum yields and remarkable emission in the NIR region for $\mathrm{Nd}-, \mathrm{Sm}^{-}$and Ho-based compounds. 
We also demonstrate that it is possible to prepare molecular alloys based on iso-structural lanthanide complexes of formula $\left[\operatorname{Ln}_{1-x} \operatorname{Ln}_{x}{ }_{x}(\text { phen })_{2}\left(\mathrm{NO}_{3}\right)_{3}\right]$ and not only based on coordination polymers. To the best of our knowledge this has not been demonstrated before. However, this series of compounds exhibits emission color and intensity modulations that are not as good as expected. This is due to the presence of efficient inter-metallic energy transfers despite long intermetallic distances. An explanation could be that the stacked phen ligands are efficient in mediating such energy transfers in this system.

Nevertheless, on the basis of this study it clearly appears that molecular alloys of lanthanide complexes could present interesting luminescent properties that could find their application in the fields of displays or anti-counterfeiting taggants.

\section{SUPPORTING INFORMATIONS}

Solid state IR spectrum of 1; TG/TD analyses for 1; Powder X-ray diffraction diagrams of $\left[\mathrm{Tb}_{1-x} \mathrm{Eu}_{x}(\text { phen })_{2}\left(\mathrm{NO}_{3}\right)_{3}\right]$ with $0 \leq x \leq 1$; Powder $\mathrm{X}$-ray diffraction diagrams of $\left[\mathrm{Tb}_{1-x} \mathrm{Gd}_{x}(\text { phen })_{2}\left(\mathrm{NO}_{3}\right)_{3}\right] \quad 0 \leq x \leq 1$; Experimental and simulated powder X-ray diffraction patterns of compounds $\left[\mathrm{Ln}(\mathrm{phen})_{2}\left(\mathrm{NO}_{3}\right)_{3}\right]$ with $\mathrm{Ln}=\mathrm{Sm}$ (simulated), $\mathrm{Y}_{0.75} \mathrm{Lu}_{0.25}$; Metallic contents measured by EDS for $\left[\mathrm{Tb}_{1-x} \mathrm{Eu}_{x}(\text { phen })_{2}\left(\mathrm{NO}_{3}\right)_{3}\right]$ with $0<x<1$; Metallic contents measured by EDS for $\left[\mathrm{Gd}_{1-x} \mathrm{~Tb}_{x}(\text { phen })_{2}\left(\mathrm{NO}_{3}\right)_{3}\right]$ with $0<x<1$; Selected interatomic distances ( $\AA$ ) and bond angles $\left(^{\circ}\right)$ for $\left[\mathrm{Sm}(\text { phen })_{2}\left(\mathrm{NO}_{3}\right)_{3}\right](\mathbf{1})$. 


\section{REFERENCES}

1. Batten, S. R., Coordination polymers. Curr. Opin. Solid State Mater. Sci. 2001, 5, 107-114.

2. Robin, A. Y.; Fromm, K. M., Coordination polymer networks with O- and N-donnors: What they are, why and how they are made? Coord. Chem. Rev. 2006, 250, 2127-2157.

3. Bunzli, J.-C. G.; Piguet, C., Taking advantage of luminescent lanthanide ions. Chemical Society Reviews 2005, 34, 1048-1077.

4. Bünzli, J.-C. G., Lanthanide luminescence for biomedical analyses and imaging. Chem. Rev. 2010, 111, 2729-2755.

5. Bünzli, J. C. G., Rising stars in science and technology : Luminescent lanthanide materials. Eur. J. Inorg. Chem. 2017, 5058-5063.

6. Cui, Y.; Li, B.; He, H.; Zhou, W.; Chen, B.; Qian, G., Metal-organic frameworks as platforms for functionnal materials. Accounts Chem. Res. 2016, 49, 483-493.

7. Cui, Y.; Zhang, J.; He, H.; Qian, G., Photonic functional metal-organic frameworks. Chem. Soc. Rev. 2018, 47, 5740-5785.

8. Guillou, O.; Daiguebonne, C.; Calvez, G.; Bernot, K., A long journey in lanthanide chemistry : from fundamental crystallogenesis studies to commercial anti-counterfeiting taggants. Accounts Chem. Res. 2016, 49, 844-856.

9. Binnemans, K., Lanthanide based luminescent hybrid materials. Chem. Rev. 2009, 109, 42834374.

10. Lustig, W. P.; Li, J., Luminescent metal organic frameworksand coordination polymers as alternative phosphors for energy efficient lighting devices. Coord. Chem. Rev. 2018, 373, 116-147.

11. Gatteschi, D.; Sessoli, R.; Villain, J., Oxford University Press: Oxford, 2006.

12. Sessoli, R.; Bernot, K., Lanthanides in extended molecular networks. In Molecular magnetism, Wiley-VCH Verlag GmbH \& Co. KGaA: 2015, p 89-124.

13. Clérac, R.; Winpenny, R. E. P., Single-molecule magnets and related phenomena. In 50 years of structure and bonding - The anniversary volume, Mingos, D. M. P., Ed. Springer International Publishing: Cham, 2016, p 35-48.

14. Bünzli, J. C. G.; Eliseeva, S. V., Basics of lanthanide photophysics. In Lanthanide Luminescence, Hänninen, P.; Härmä, H., Eds. Springer Berlin Heidelberg: 2010; Vol. 7, p 1-45.

15. Weissman, S. I., Intramolecular energy transfer - The fluorescence of complexes of europium. J. Chem Phys 1942, 10, 214-217.

16. Dechambenoit, P.; Ferlay, S.; Kyritsakas, N.; Hosseini, M. W., Playing with isostructurality : from tectons to molecular alloys and composite crystals. Chem. Comm. 2009, 1559-1561.

17. Le Natur, F.; Calvez, G.; Daiguebonne, C.; Guillou, O.; Bernot, K.; Ledoux, J.; Le Polles, L.; Roiland, C., Coordination polymers based on hexanuclear rare earth complexes : Toward independant luminescence brightness and color emission. Inorg. Chem. 2013, 52, 6720-6730.

18. Fan, X.; Freslon, S.; Daiguebonne, C.; Calvez, G.; Le Polles, L.; Bernot, K.; Guillou, O., Heteronuclear lanthanide-based coordination polymers exhibiting tunable multiple emission spectra. J. Mater. Chem. C 2014, 5510-5525.

19. Fan, X.; Freslon, S.; Daiguebonne, C.; Le Polles, L.; Calvez, G.; Bernot, K.; Guillou, O., A family of lanthanide based coordination polymers with boronic acid as ligand. Inorg. Chem. 2015, 54, 55345546 .

20. Cui, Y.; Xu, H.; Yue, Y.; Guo, Z.; Yu, J.; Chen, Z.; Gao, J.; Yang, Y.; Qian, G.; Chen, B., A Luminescent mixed-lanthanide Metal-Organic Framework thermometer. J. Am. Chem. Soc. 2012, 134, 3979-3982.

21. Cui, Y.; Zou, W.; Song, R.; Yu, J.; Zhang, W.; Yang, Y.; Qian, G., A ratiometric and colorimetric luminescent thermometer over a wide temperature range based on a lanthanide coordination polymer. Chem. Comm. 2014, 50, 719-721.

22. Wang, H.-L.; Ma, X.-F.; Zou, H.-H.; Wang, K.; Li, B.; Chen, Z.-L.; Liang, F.-P., Mixed chelating ligands used to regulate the luminescence of $\operatorname{Ln}(\mathrm{III})$ complexes and single ion magnet behavior in Dybased analogues. Dalton Trans. 2018, 47, 15929-15940. 
23. Zheng, Y.-Q.; Zhou, L.-X.; Lin, J.-L.; Zhang, S.-W., Crystal structure of tris(nitrato-O,O')bis(1,10-phenantroline-N, $\left.\mathrm{N}^{\prime}\right)$-yttrium(III), $\mathrm{Y}(\mathrm{phen})_{2}\left(\mathrm{NO}_{3}\right)_{3}$. Z. Kristallogr. NCS 2001, 216, 357-358.

24. Fréchette, M.; Butler, I. R.; Hynes, R.; Detellier, C., Structures in solution and in the solid state of the complexes of lanthanum(III) with 1,10-phenantroline. X-ray crystallographic and ${ }^{1} \mathrm{H},{ }^{13} \mathrm{C},{ }^{17} \mathrm{O}$ and ${ }^{139}$ La solution NMR studies. Inorg. Chem. 1992, 31, 1650-1656.

25. Sadikov, G. G.; Antsyshkina, A. S.; Rodnikova, M. N.; Solonina, I. A., Intracomplex $\pi-\pi$ stacking interaction between adjacent phenanthroline molecules in complexes with rare-earth nitrates: Crystal and molecular structures of bis(1,10-Phenanthroline)trinitratoytterbium and bis $(1,10-$ Phenanthroline)trinitratolanthanum. Crystallogr. Rep. 2009, 54, 48-58.

26. Lin, Q.-L.; Feng, Y.-L., Crystal structure of tris(nitrato-O,O')bis(1,10-phenantroline-N,N')cerium(III), $\mathrm{Ce}\left(\mathrm{NO}_{3}\right)_{3}\left(\mathrm{C}_{12} \mathrm{H}_{8} \mathrm{~N}_{2}\right)_{2}$. Z. Kristallogr. NCS 2003, 218, 531-532.

27. Zheng, Y. Q.; Zhou, L.-X.; Lin, J.-L., Syntheses and crystal structures of $\operatorname{Ln}($ phen)2(NO3)3 with $\mathrm{Ln}=\mathrm{Pr}, \mathrm{Nd}, \mathrm{Sm}, \mathrm{Eu}$, Dy and phen =1,10-phenantroline. Z. Anorg. Allg. Chem. 2001, 627, 1643-1646.

28. Singh, U. P.; Goel, N.; Singh, G.; Srivastava, P., Syntheses, structural and thermal studies of $\mathrm{Eu}(\mathrm{III})$ and $\mathrm{Gd}(\mathrm{III})$ complexes with 2,6-dinitrophenol and 1,10-phenantroline/2,2'-bipyridine ligands. Inorg. Chim. Acta 2012, 387, 294-307.

29. Ananyav, I. V.; Nelyubina, L. N.; Lyssenko, K. A.; Eremenko, I. L., Peculiarities of metal-ligand bonding in europium trinitrate complexes: a viewpoint of comparative charge density analysis in crystals. Russian Chemical Bulletin, International Edition 2016, 65, 1178-1188.

30. Werner, F.; Tada, K.; Ishii, A.; Takata, M.; Hasegawa, M., The key role of accurate lattice parameters in revealing subtle structuraldifferences - a case study in the system [ $\operatorname{Ln}(\mathrm{phen} / \mathrm{phen}$ $\left.\left.\mathrm{d}_{8}\right)_{2}\left(\mathrm{NO}_{3}\right)_{3}\right]$. Cryst. Eng. Comm. 2009, 11, 1197-1200.

31. Sadikov, G. G.; Antsyshkina, A. S.; Kuznetsova, I. A.; Rodnikova, M. N., Synthesis and Structure of Two Crystalline Modifications of Bis(1,10-Phenanthroline)trinitratoeuropium(III) $\mathrm{Eu}\left(\mathrm{NO}_{3}\right)_{3}(\mathrm{Phen})_{2}$. Crystallogr. Rep. 2006, 51, 53-58.

32. Pan, Z.; Jia, G.; Duan, C.-K.; Wong, W.-Y.; Wong, W.-T.; Tanner, P. A., Crystal Structure, Spectroscopy and Crystal Field Analysis of Substituted1,10-Phenanthroline-Europium Complexes. Eur. J. Inorg. Chem. 2011, 637-646.

33. Wei, D.-Y.; Lin, J.-L.; Zheng, Y.-Q., The crystal structure of tris(nitrato-O,O')bis(1,10phenantroline-N,N')terbium(III). J. Coord. Chem. 2002, 55, 1259-1262.

34. She, S.; Su, G.; Wang, B.; Lei, Q.; Yang, Y.; Gong, L.; Liu, B., Two dysprosium(III)-based single molecule magnets derived from 1,10-phenantroline ligands and different anions as bridging groups. Eur. J. Inorg. Chem. 2017, 2406-2412.

35. Kusrini, E.; Saleh, M. I.; Kia, R.; Fun, H.-K., Tris(nitrato- $\left.\kappa^{2} \mathrm{O}, \mathrm{O}^{\prime}\right)$ bis(1,10-phenantroline$\kappa^{2} \mathrm{~N}, \mathrm{~N}^{\prime}$ )holmium(III). Acta Crystallogr. E 2008, E64, m1014-m1015.

36. Sadikov, G. G.; Antsyshkina, A. S.; Kuznetsova, I. A.; Rodnikova, M. N., Synthesis and the Crystal and Molecular Structure of Two Modifications of Bis(1,10-Phenanthroline)trinitratoerbium(III) $\mathrm{Er}\left(\mathrm{NO}_{3}\right)_{3}(\text { Phen })_{2}$. Crystallogr. Rep. 2006, 51, 271-277.

37. Liu, Y.-F.; Xia, H.-T.; Yang, S.-P.; Wang, D.-Q., Tris(nitrato- $\left.\kappa^{2} \mathrm{O}, \mathrm{O}^{\prime}\right)$ bis $(1,10-$ phenanthroline$\left.\kappa^{2} \mathrm{~N}, \mathrm{~N}^{\prime}\right) y t t e r b i u m(I I I)$. Acta Crystallogr. E 2007, E63, m12-m14.

38. Kepert, D. L.; Semenova, L. I.; Sobolev, A. N.; White, A. H., Structural systematics of rare earth complexes. IX. Tris(nitrato-O,O')(bidentate-N,N')lutetium(III), N, $\mathrm{N}^{\prime}$-bidentate $=2,2^{\prime}$-bypiridine or 1,10phenantroline. Aust. J. Chem. 1996, 49, 1005-1008.

39. Li, X.; Zhang, Y.-B.; Zou, Y.-Q., Hydrothermel synthesis, crystal structure and luminescence of lanthanide(III) coordination polymers with tetrafluorosuccinate and 1,10-phenantroline. J. Mol. Struc. 2009, 919, 277-283.

40. Nakamoto, K., Infrared and raman spectra of inorganic and coordination compounds Part A: Theory and applications in inorganic chemistry, 6th edition. 6th edition ed.; John Wiley \& sons Inc: Hoboken, NJ, 2009.

41. Oczko, G.; Legendziewicz, J.; Wickleder, M. S.; Meyer, G., Crystal structure, magnetism and photophysics of the lanthanide maleates $\mathrm{RE}\left(\mathrm{C}_{4} \mathrm{O}_{4} \mathrm{H}_{3}\right)_{3} .8 \mathrm{H}_{2} \mathrm{O}$. J. Alloys Compd. 2002, 341, 255-262. 
42. Kraus, W.; Nolze, G., POWDER CELL - A program for the representation and manipulation of crystal structures and calculation of the resulting X-ray powder patterns. J. Appl. Crystallogr. 1996, 29, 301-303.

43. Roisnel, T.; Rodriguez-Carjaval, J., A Window Tool for Powder Diffraction Patterns Analysis. J. Mater. Sci. Forum 2001, 378, 118-123.

44. Roisnel, T.; Rodriguez-Carjaval, J., WinPLOTR : a windows tool for powder diffraction pattern analysis. Materials Science Forum, Proceedings of the Seventh European Powder Diffraction Conference (EPDIC 7) 2000, 118-123.

45. Haquin, V.; Etienne, M.; Daiguebonne, C.; Freslon, S.; Calvez, G.; Bernot, K.; Le Polles, L.; Ashbrook, S. E.; Mitchell, M. R.; Bünzli, J. C. G.; Guillou, O., Color and brightness tuning in heteronuclear lanthanide teraphthalate coordination polymers. Eur. J. Inorg. Chem. 2013, 3464-3476.

46. CIE, International Commission on Illumination - Technical report. CIE: 1995; Vol. 13-3, p 16.

47. Wyszecki, G., Colorimetry. In Handbook of Optics, Driscoll, W. G.; Vaughan, W., Eds. Mac Graw-Hill Book Company: New-York, 1978, p 1-15.

48. Altomare, A.; Burla, M. C.; Camalli, M.; Cascarano, G.; Giacovazzo, C.; Guagliardi, A.; Moliterni, A. G. G.; Polidori, G.; Spagna, R., SIR97: a new tool for crystal structure determination and refinement J. Appl. Crystallogr. 1999, 32, 115-119.

49. Farrugia, L. J., WinGX suite for smallmolecule single-crystal crystallography. J. Appl. Crystallogr. 1999, 32, 837-838.

50. Farrugia, L. J., WinGX and ORTEP for Windows: an update. J. Appl. Crystallogr. 2012, 45, 849-

854.

51. Sheldrick, G. M.; Schneider, T. R., SHELXL : High-Resolution Refinement. Macromol. Crystallogr. B 1997, 319-343.

52. Luo, Y.; Zheng, Y.; Calvez, G.; Freslon, S.; Bernot, K.; Daiguebonne, C.; Roisnel, T.; Guillou, O., Synthesis, crystal structure and luminescent properties of new lanthanide-containing coordination polymers Involving 4,4'-oxy-bis-benzoate as Ligand. Cryst. Eng. Comm. 2013, 15, 706-720.

53. Piguet, C.; Bünzli, J. C. G.; Bernardinelli, G.; Hopfgatner, G.; Williams, A. F., Self-assembly and photophysical properties of lanthanide dinuclear triple-helical complexes. J. Am. Chem. Soc. 1993, 115, 8197-8206.

54. Dexter, D. L., A theory of sensitized luminescence in solids. J. Chem. Phys. 1953, 21, 836-850.

55. Förster, T., Comparative effects of radiation. John Wiley \& Sons: New-York, 1960.

56. Carnall, W. T.; Fields, P. R.; Rajnak, K., Spectral intensities of the trivalent lanthanides and actinides in solution. II. $\mathrm{Pm}^{3+}, \mathrm{Sm}^{3+}, \mathrm{Eu}^{3+}, \mathrm{Gd}^{3+}, \mathrm{Tb}^{3+}, \mathrm{Dy}^{3+}$ and $\mathrm{Ho}^{3+}$. J. Chem. Phys. 1968, 49, 44124423.

57. Xu, Y.-Y.; Chen, P.; Gao, T.; Li, H.-F.; Yan, P.-F., White-light emission based on a single component Sm(III) complex and enhanced optical properties by doping methods. Cryst. Eng. Comm. 2019, 21, 964-970.

58. Zhang, Y.-H.; Li, X.; Song, S., White light emission based on a single component Sm(III) framework and a two component $\mathrm{Eu}(\mathrm{III})$-doped $\mathrm{Gd}(\mathrm{III})$ framework constructed from 2,20diphenyldicarboxylate and $1 \mathrm{H}$-imidazo[4,5-f ][1,10]-phenanthroline. Chem. Comm. 2013, 49, 1039710399.

59. Abdallah, A.; Freslon, S.; Fan, X.; Rojo, A.; Daiguebonne, C.; Suffren, Y.; Bernot, K.; Calvez, G.; Roisnel, T.; Guillou, O., Lanthanide based coordination polymers with 1,4 carboxyphenylboronic ligand: multi emissive compounds for multi sensitive luminescent thermometric probes. Inorg. Chem. 2019, 58, 462-475.

60. Xiao, Y.; Wang, S.-H.; Zheng, F.-K.; Wu, M.-F.; Xu, J.; Liu, Z.-F.; Chen, J. E.; Li, R.-W.; Guo, G.-C., Excitation wavelength-induced color tunable and white-light emissions in lanthanide(III) coordination polymers constructed by an environment-dependent luminescent tetrazolate-dicarboxylate ligand. Cryst. Eng. Comm. 2016, 18, 721-727.

61. Carnall, W. T.; Fields, P. R.; Rajnak, K., Energy levels in the trivalent lanthanide ions. III. Tb ${ }^{3+}$. J. Chem. Phys. 1968, 49, 4447-4450. 
62. Badiane, A. M.; Freslon, S.; Daiguebonne, C.; Suffren, Y.; Bernot, K.; Calvez, G.; Costuas, K.; Camara, M.; Guillou, O., Lanthanide based coordination polymers with a 4,5-dichlorophthalate ligand exhibiting highly tunable luminescence : Toward luminescent bar codes. Inorg. Chem. 2018, 57, 33993410.

63. Badiane, I.; Freslon, S.; Suffren, Y.; Daiguebonne, C.; Calvez, G.; Bernot, K.; Camara, M.; Guillou, O., High britness and easy color modulation in lanthanide-based coordination polymers with 5-methoxyisophthalate as ligand: Toward emission colors additive strategy. Cryst. Growth Des. 2017, 17, 1224-1234.

64. Carnall, W. T.; Fields, P. R.; Wybourne, B. G., Spectral intensities of the trivalent lanthanides and actinides in solution. I. $\mathrm{Pr}^{3+}, \mathrm{Nd}^{3+}, \mathrm{Er}^{3+}, \mathrm{Tm}^{3+}$ and $\mathrm{Yb}^{3+}$. J. Chem. Phys. 1965, 42, 3797-3806.

65. Carnall, W. T.; Fields, P. R.; Rajnak, K., Electronic energy levels of the trivalent lanthanide ions. IV. Eu ${ }^{3+}$. J. Chem. Phys. 1968, 49, 4450-4455.

66. D'Aléo, A.; Pointillart, F.; Ouahab, L.; Andraud, C.; Maury, O., Charge transfer excited states sensitization of lanthanide emitting from the visible to near infra red. Coord. Chem. Rev. 2012, 256, 1604-1620.

67. Latva, M.; Takalo, H.; Mukkala, V.-M.; Matachescu, C.; Rodriguez-Ubis, J. C.; Kankare, J., Correlation between the lowest triplet state energy level of the ligand and lanthanide luminescence quantum yields. J. Lumin. 1997, 75, 149-169.

68. Bhaumik, M. L.; Nugent, L. J., Time-Resolved Spectroscopy of Europium Chelates. J. Chem. Phys. 1965, 43, 1680-1687.

69. Dawson, W. R.; Kropp, J. L.; Windsor, M. W., Internal-Energy-Transfer Efficiencies in Eu ${ }^{3+}$ and $\mathrm{Tb}^{3+}$ Chelates Using Excitation to Selected Ion Levels. J. Chem. Phys. 1966, 45, 2410-2418.

70. Beeby, A.; Bushby, L. M.; Maffeo, D.; William, J. A. G., The efficient intramolecular sensitisation of terbium(III) and europium(III) by benzophenone-containing ligands. Journal of the Chemical Society Perkin Transactions 2 2000, 1281-1283.

71. van der Tol, E. B.; van Ramesdok, H. J.; Verhoeven, J. W.; Steemers, F. J.; Kerver, E. G.; Verboom, W.; Reinhoudt, D. N., Tetraazatriphenylenes as Extremely Efficient Antenna Chromophoresfor Luminescent Lanthanide Ions. Chem. - Eur. J. 1998, 4, 2315-2322.

72. Abdallah, A.; Daiguebonne, C.; Suffren, Y.; Rojo, A.; Demange, V.; Bernot, K.; Calvez, G.; Guillou, O., Microcrystalline core-shell lanthanide-based coordination polymers for unprecedented luminescent properties. Inorg. Chem. 2019, 58, 1317-1329.

73. Piguet, C.; Williams, A. F.; Bernardinelli, G.; Moret, E.; Bünzli, J. C. G., Structural and photophysical properties of lanthanide nitrate $1: 1$ complexes with planar tridentate nitrogen ligands analogous to 2,2': 6',2"-terpyridine. Helvetica Chimica Acta 1992, 75, 1697-1717. 


\section{GRAPHICAL ABSTRACT}

Lanthanide complex-based molecular alloys can exhibit interesting luminescent properties and can be good candidates for efficient luminescent coordination materials.

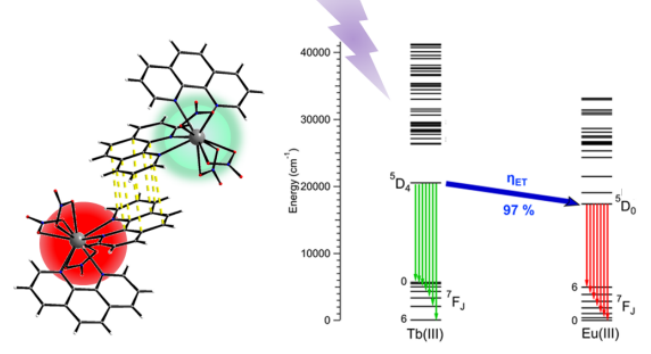

